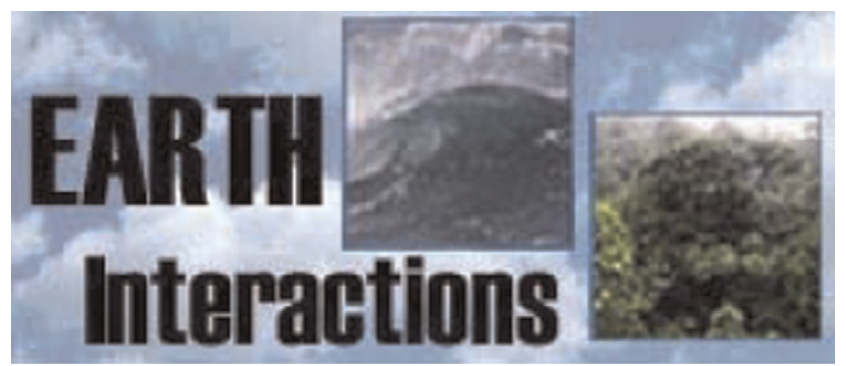

Copyright $\odot$ 2011, Paper 15-016; 12814 words, 8 Figures, 0 Animations, 3 Tables. http://EarthInteractions.org

\title{
Impacts of Climate Change and the End of Deforestation on Land Use in the Brazilian Legal Amazon
}

\section{David Montenegro Lapola, ${ }^{*++}$ Ruediger Schaldach, and Joseph Alcamo}

Center for Environmental Systems Research, University of Kassel, Kassel, Germany

\section{Alberte Bondeau}

Potsdam Institute for Climate Impact Research, Potsdam, Germany

\section{Siwa Msangi}

International Food Policy Research Institute, Washington, D.C.

\section{Joerg A. Priess}

Helmholtz-Centre for Environmental Research, Leipzig, Germany

\section{Rafaella Silvestrini and Britaldo Silveira Soares-Filho}

Centro de Sensoriamento Remoto, Universidade Federal de Minas Gerais, Belo Horizonte, Brazil

Received 11 February 2010; accepted 14 November 2010

ABSTRACT: Climate change scenarios vary considerably over the Amazon region, with an extreme scenario projecting a dangerous (from the human

* Current affiliation: Departamento de Ecologia, Instituto de Biociências, Universidade Estadual Paulista, Rio Claro, Brazil.

+ Corresponding author address: David M. Lapola, Departamento de Ecologia, Instituto de Biociências, Universidade Estadual Paulista, Av. 24-A, 13500-900 Rio Claro, SP, Brazil.

E-mail address: dmlapola@yahoo.com.br 
Earth Interactions - Volume 15 (2011) • Paper No. 16 • Page 2

perspective) increase of $3.8^{\circ} \mathrm{C}$ in temperature and $30 \%$ reduction in precipitation by 2050 . The impacts of such climate change on Amazonian land-use dynamics, agricultural production, and deforestation rates are still to be determined. In this study, the authors make a first attempt to assess these impacts through a systemic approach, using a spatially explicit modeling framework to project crop yield and land-use/land-cover changes in the Brazilian Amazon by 2050. The results show that, without any adaptation, climate change may exert a critical impact on the yields of crops commonly cultivated in the Amazon (e.g., soybean yields are reduced by $44 \%$ in the worst-case scenario). Therefore, following baseline projections on crop and livestock production, a scenario of severe regional climate change would cause additional deforestation of $181000 \mathrm{~km}^{2}(+20 \%)$ in the Amazon and $240000 \mathrm{~km}^{2}(+273 \%)$ in the Cerrado compared to a scenario of moderate climate change. Putting an end to deforestation in the Brazilian Amazon forest by 2020 (and of the Cerrado by 2025 ) would require either a reduction of $26 \%-40 \%$ in livestock production until 2050 or a doubling of average livestock density from 0.74 to 1.46 head per hectare. These results suggest that (i) climate change can affect land use in ways not previously explored, such as the reduction of yields entailing further deforestation, and (ii) there is a need for an integrated/multidisciplinary plan for adaptation to climate change in the Amazon.

KEYWORDS: Tropical agriculture; Cattle ranching; Climate change adaptation; Integrated assessment; Cerrado

\section{Introduction}

The Amazon has been recognized as a region particularly vulnerable to climate change over this century (Lenton et al. 2008; Malhi et al. 2008). Although climate change scenarios for the region differ considerably ( $\mathrm{Li}$ et al. 2006), the high end of projections show a temperature increase of $3.8^{\circ} \mathrm{C}$ and up to $30 \%$ reduction in precipitation by 2050 (Figure 1). The impacts of such regional climate change and of the projected "forest dieback" on the vegetation dynamics, water and carbon cycle, and feedbacks with the global climate system have been extensively investigated in the last decade (Cox et al. 2000; Cox et al. 2004; Cramer et al. 2001; Huntingford et al. 2004; Huntingford et al. 2008; Sitch et al. 2008; Lapola et al. 2009a). In addition, field observations (Gash and Nobre 1997) as well as modeling studies (Nobre et al. 1991; Costa and Foley 2000; Sampaio et al. 2007) have shown that there is considerable change in the local and regional climate after the replacement of forest by pasture or crops. On the other hand, considerably less research has been done to assess the effects of future climate on land-use and landcover dynamics in the Amazon region.

Recent extreme climate events, like the 1997/98 El Niño drought (Nepstad et al. 1999a) or the droughts of 2005 (Marengo et al. 2008) and 2010 (Lewis et al. 2011), brought considerable reductions in crop/pasture productivity and food shortage, among a variety of other relevant impacts inside and outside the Amazon (Nepstad et al. 1999b; Nepstad et al. 2001; Moran et al. 2006; Brondizio and Moran 2008; Lenton et al. 2009). Modeling studies by Cox et al. (Cox et al. 2000; Cox et al. 2004; Cox et al. 2008) project a future in which the Amazon would be exhibited in a permanent El Niño-like climate after 2040 and that events like the 2005 drought will increase in frequency from a 1-in-20-yr event to a 16-in-20-yr event by 2050. 

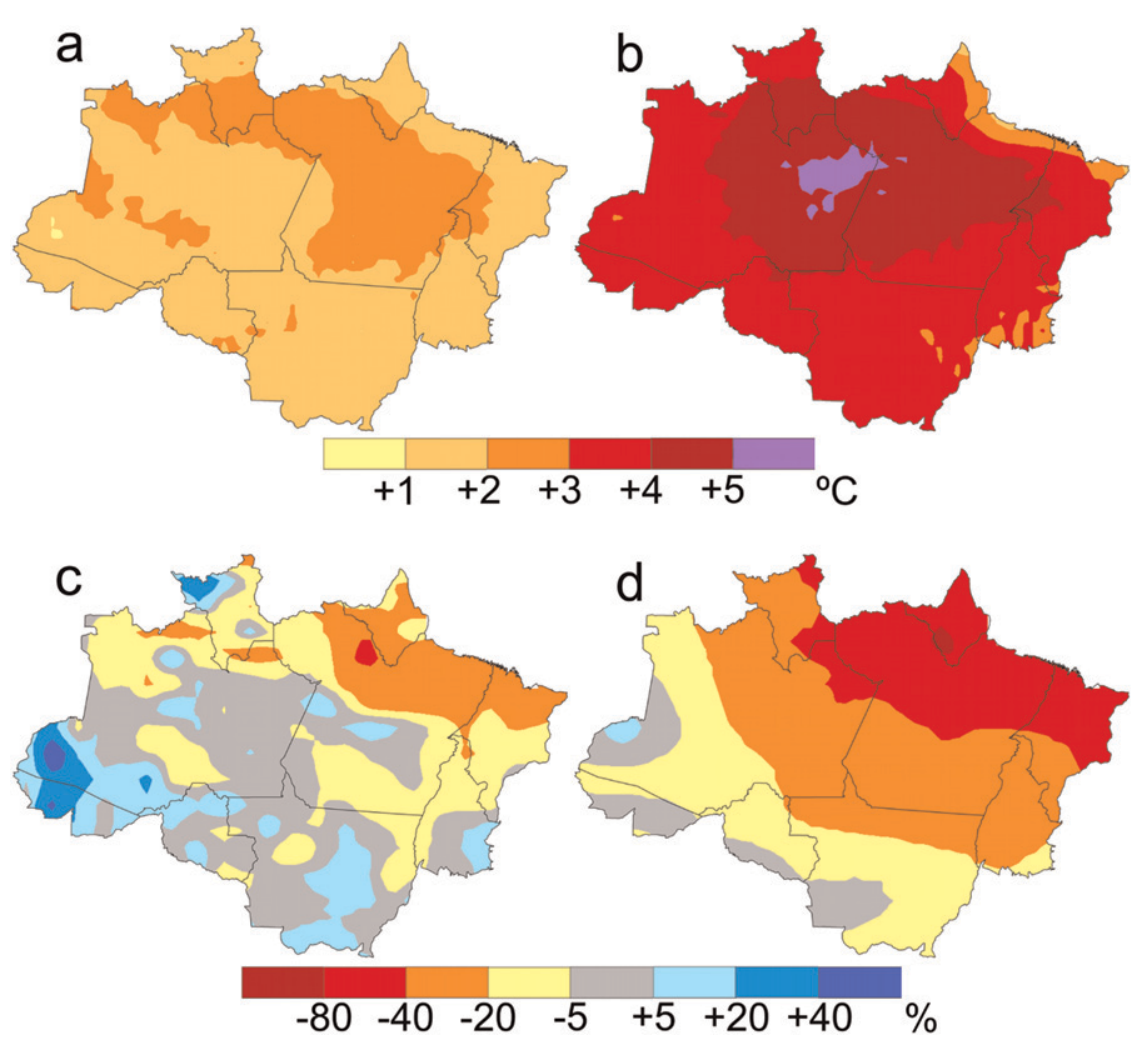

Figure 1. Anomalies of $(a),(b)$ temperature and (c), (d) precipitation in (a), (c) a moderate climate change scenario (CCSM3) and (b),(d) a severe climate change scenario (HadCM3) projected for 2036-65 under SRES A2 compared to 1961-90 in the Brazilian Legal Amazon.

Therefore, in light of the impact extreme climate events had on agriculture in the past and considering that these events might come close to the future "norm" (Battisti and Naylor 2009), the impacts of future climate change on land-use and land-cover change are highly relevant (see Lambin and Geist 2006, p. 174).

Agricultural activities are now solidly established in the Brazilian Amazon (Nepstad et al. 2006), especially the lucrative soybean farming, which had an increase in area from $16000 \mathrm{~km}^{2}$ in 1990 to $60000 \mathrm{~km}^{2}$ in 2008 (IBGE 2010). Nearly $36 \%$ of the Brazilian cattle herd and pasture area is currently located in the Legal Amazon, ${ }^{1}$ the only region in the country that has experienced an increase in pasture area in the last two decades (IBGE 2010; Barreto et al. 2008). Moreover, the Legal Amazon currently contributes $15 \%$ of the national agricultural gross domestic product (GDP) and had a (total) GDP growth of $6.6 \% \mathrm{yr}^{-1}$ in the 19992008 period, compared to the national average of $3.4 \% \mathrm{yr}^{-1}$ (Tomazela 2007;

\footnotetext{
${ }^{1}$ The Brazilian states of Acre, Amapá, Amazonas, Mato Grosso, Rondônia, Roraima, Tocantins, and (part of) Maranhão. The Legal Amazon comprises $61 \%$ of the national territory, roughly $62 \%$ of the Amazon forest area (Soares-Filho et al. 2006), and has a population of 23 million people (IBGE 2010).
} 
Earth Interactions - Volume 15 (2011) • Paper No. 16 • Page 4

Salomon 2008). On the other hand, this surge of the Amazon economy was accompanied by increasing conservation concerns. For example, more than $75 \%$ of the area under strict protection in the Brazilian Amazon has been enacted after 1990 (ISA 2010), and since 2002 the protected area network has increased by $6400 \mathrm{~km}^{2}$, now covering $51 \%$ of the remaining forest (Soares-Filho et al. 2010). In 2008, the Brazilian government made a formal announcement within the United Nations climate treaty framework of reducing Amazon deforestation by $80 \%$ compared to the historical rate of $19500 \mathrm{~km}^{2} \mathrm{yr}^{-1}$ by 2020 (Government of Brazil 2008; Nepstad et al. 2009). The interplay between these two apparently antagonistic issues (high growth of agricultural economy and the end of deforestation) in view of future climate change and growing demands for land (for food, feed, and biofuel production) calls for in-depth scientific research to provide a sound foundation for decision making.

Here, we applied a spatially explicit modeling framework to assess the impacts of climate change and conservation targets on land-use and land-cover changes (LUCC) in the Legal Amazon by 2050, taking into account projected levels of crop and livestock production. In this study, LUCC are affected by climate change via crop/pasture productivity. Two different scenarios of climate change are used, namely, moderate and extreme regional climate change. Additionally, we also investigate how 2050 crop and livestock production demands could be conciliated with the end of deforestation in the Brazilian Amazon forest and Cerrado savanna in the 2020s (Nepstad et al. 2009).

\section{Methods}

\subsection{Model description}

The central feature of our modeling framework is the Land Simulation to Harmonize and Integrate Freshwater Availability and the Terrestrial Environment (LandSHIFT) model, which simulates land-use and land-cover change on a 5-arcmin spatial resolution (Schaldach and Koch 2009). By using a "land-use systems" approach, it describes the interplay between anthropogenic and environmental system components as drivers for land-use change in three major land-use activities (settlement, crop cultivation, and grazing) and their competition for land resources. Moreover, LandSHIFT's livestock module simulates not only the occurrence of pastures but also the intensity of grazing. The model has been applied and evaluated in assessments of the impact of grazing management in the Jordan River region (Koch et al. 2008), the quantification of future LUCC and water use by agriculture in Africa (Weiß et al. 2009), and LUCC associated with increased production of biofuels in Brazil (Lapola et al. 2010) and India (Schaldach et al. 2011).

The International Model for Policy Analysis of Agricultural Commodities and Trade (IMPACT) (Rosegrant et al. 2008) provides future projections of crop/ livestock production in the Legal Amazon, and the International Futures (IFs) model (Hughes 1999) projects population growth. Because the latter projects population growth on country level, we assumed the Legal Amazon to entire Brazil population ratio of 0.12 in 2007 to be constant until 2050. The Lund-Potsdam-Jena (LPJ) Dynamic Global Vegetation Model for Managed Lands (LPJmL) is used to calculate crop and grassland potential productivity on a $0.5^{\circ}$ resolution grid 


\section{Earth Interactions - Volume 15 (2011) • Paper No. 16 • Page 5}

(Bondeau et al. 2007). These three models (IMPACT, IFs, and LPJmL) provide inputs to LandSHIFT, even though they are not dynamically coupled to LandSHIFT. However, though the exchange of information between the models is unidirectional (from IMPACT and LPJmL to LandSHIFT), the assumptions used to generate their outputs are compatible. For example, the baseline scenario of IMPACT is consistent with the Special Report on Emission Scenarios (SRES) A2 emission scenario used to compute future crop yields with LPJmL (in terms of projected population and economical growth; see next section).

Starting from an initial land-use map (see appendix A), the spatial allocation of different land uses in subsequent time steps is based on a multicriteria suitability analysis following the equation

$$
\psi_{k}=\underbrace{\sum_{i=1}^{n} w_{i} p_{i, k}}_{\text {suitability }} \times \underbrace{\prod_{j=1}^{m} c_{j, k}}_{\text {constraints }}, \text { with } \sum_{i} w_{i}=1, \text { and } p_{i, k}, c_{j, k} \in[0,1],
$$

where the factor weight $w_{i}$ determines the importance that each suitability factor $p_{i}$ has at grid cell $k$, whereas $c_{j}$ represents possible constraints for changing the landuse type at that given cell. In this study, $p_{i}$ includes slope, distance to paved roads, distance to all roads, vegetation type (for sources, see Soares-Filho et al. 2006), potential crop/grassland yield (from the LPJmL model), proximity to cropland, attraction to national markets (see below), and distance to deforested land. The latter is used only for grazing because it has the same effect as proximity to cropland in crop cultivation. Therefore, $n=7$ for crop cultivation and $n=8$ for grazing. Paved roads are updated following the road paving schedule in the study by Soares-Filho et al. (Soares-Filho et al. 2006). Secondary roads are updated using the outputs of the road constructor submodel of the "SimAmazonia 1" model of land-cover changes (Soares-Filho et al. 2006) under a "business as usual" (BAU) scenario, which is consistent with the aforementioned paving schedule. The attraction to national markets factor represents the influence of the Brazilian cities that are the biggest consumers of Amazonian agricultural products, especially meat. These cities are located in southeast and northeast Brazil (Barreto et al. 2008). The index is calculated using a unidirectional gravity-type model,

$$
\mathrm{NMa}_{k}=\sum_{v} \frac{\operatorname{Pop}_{v}}{d_{k}^{2}},
$$

where $\mathrm{NMa}_{k}$ is the national markets attraction exerted in the grid cell $k$, determined by summing up the population of the five most populous cities in southeast and northeast Brazil ( $v=5$ : São Paulo, Rio de Janeiro, Belo Horizonte, Salvador, and Fortaleza) weighted by the distance of these cities to the cell $k$. Soil type is not considered as a $p_{i}$ factor because of its spatial correlation with the factors crop/ grass productivity and vegetation type.

Weights $w_{i}$ were determined by using the analytic hierarchy process (AHP) test (Saaty 1980). Determination of the relative importance of each $p_{i}$ factor in relation to the others $\mathrm{RI}_{\mathrm{AHP}}$, used as an entry to the AHP test, was determined by the normalized difference between the average of $p_{i}$ over areas with and without landuse changes $\varepsilon_{i}$, 


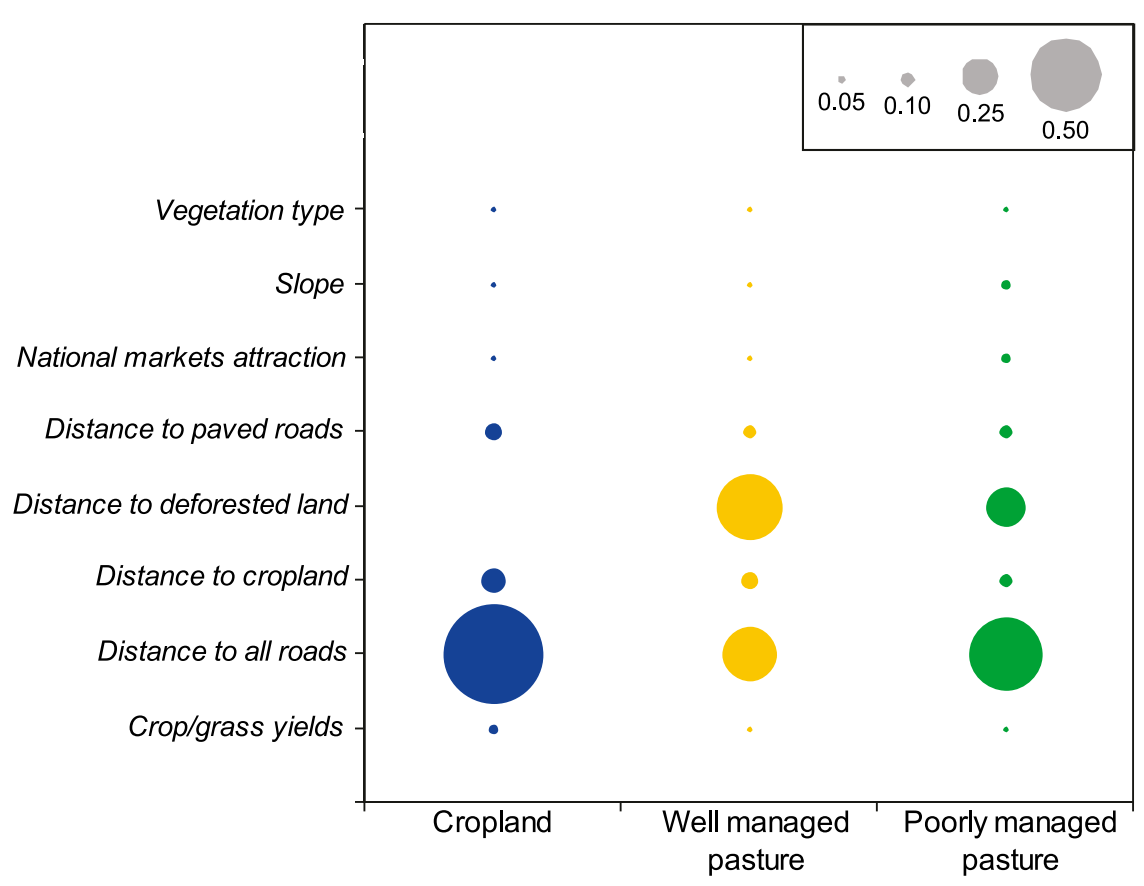

Figure 2. Weights $w_{i}$ given to each $p_{i}$ factor used in the LandSHIFT model for each of the three major land-use activities in this study. The sum of $w_{i}$ for all $p_{i}$ factors of a given land-use activity equals 1 . The distance to deforested land factor is not used for cropland allocation.

$$
\varepsilon_{i}=\left\{\begin{array}{ll}
\frac{\alpha_{i}}{\lambda_{i}} & \alpha_{i}>\lambda_{i} \\
\frac{\lambda_{i}}{\alpha_{i}} & \alpha_{i}<\lambda_{i}
\end{array}, \quad \text { with } \quad \varepsilon_{i} \in[1, \infty],\right.
$$

where $\alpha_{i}$ is the average value of variable $p_{i}$ in the grid cells where land-use change has occurred in the 2001-06 period and $\lambda_{i}$ is the average value of variable $p_{i}$ in the grid cells of the 2001 map where land-use change has not occurred (excluding the land-use activity in question: e.g., crops).

Therefore, the higher the $\varepsilon_{i}$ value, the higher the difference between the $\alpha_{i}$ and $\lambda_{i}$ averages and the importance of that $p_{i}$ factor. Then, $\mathrm{RI}_{\mathrm{AHP}}$ is determined with a pairwise comparison of $\varepsilon_{i}$ from all $p_{i}$ factors. The procedure was repeated for the three major land-use activities considered here: crop cultivation, well-managed (WM) grazing, and poorly managed (PM) grazing (Figure 2). Overall, this procedure showed that the distance to roads and the distance to previously deforested areas are the most important factors for explaining current patterns of land-use change, in agreement with the analysis by Soares-Filho et al. (Soares-Filho et al. 2006). However, other factors contribute as well to explain the different land-use activities. For example, slope has a higher importance for the location of PM pastures than for other land-use activities. Interestingly, potential crop/grass productivity does not play an important role for the location of croplands and pastures. 
Earth Interactions - Volume 15 (2011) - Paper No. 16 • Page 7

The future land-use patterns modeled by LandSHIFT in this study follow the projected changes in these factors (e.g., the road paving schedule mentioned above). Although prices are not considered as one $p_{i}$ factor influencing the spatial location of land uses, it is indirectly considered in this method. For example, the land located closer to paved roads obviously has a higher associated value or opportunity cost (see Nepstad et al. 2009) than that located farther from paved roads. The same can be deducted also from factors like slope and potential crop/ pasture yields.

Constraints $c_{j}$ comprise conservation areas and land-use transition. The level of constraint for each category of conservation area (strict protection is 0.19 , sustainable use is 0.66 , indigenous reserve is 0.54 , military reserve is 0.01 , and not protected is 1.0) was derived from the analyses by Soares-Filho et al. (Soares-Filho et al. 2006; Soares-Filho et al. 2010). In this study, the land-use transition constraints all have a value of 1.0 (i.e., no constraint), except the conversion from urban to other land use, which has a value of 0.0. The transition from forest to soybean is reduced to 0.1 after 2006 (until 2050) to simulate the soybean moratorium introduced in that year, which almost completely stopped deforestation directly caused by soybean (ABIOVE 2009).

The allocation algorithm assumes that crop cultivation takes place generally but not always in the most suitable cells for each crop/pasture type and calculates a "quasi optimum" spatial crop distribution. The Multiobjective Land Allocation (MOLA) heuristic used here seeks pattern stability and keeps previous land uses even if another crop/pasture type has a higher suitability in that cell. LPJmL potential yields are applied a crop-specific factor to match current crop yields with statistics from the study area (Schaldach and Koch 2009; IBGE 2010). These factors, which are calculated at the first simulation time step, account for uncertainties due to crop management, (e.g., multicropping) or discrepancies due to the aggregation of crop types to LPJmL crop functional types (e.g., LPJmL pulses represent extratropical pulses such as lentils). Crop production of a given grid cell $k$ is defined as the potential crop yield at $k$ multiplied by the area of $k$ that is not covered by settlement.

Allocation of both types of pasture depends on the potential productivity of grass in the grid cells, based on a livestock feed supply-demand logic. Forage supply is calculated by summing up the grass productivity of every pasture cell multiplied by the fraction of biomass that is utilized by livestock (grazing efficiency $g_{e}$ ). Here $g_{e}$ is equal to 0.37 in WM pastures and is 0.12 in PM pastures, meaning that WM pastures have a higher carrying capacity than PM pastures. These values of $g_{e}$ are based on literature (Rueda et al. 2003; Camarão et al. 2000) and calibration (only in terms of total pasture area) against the initial land-use maps. Forage demand is determined by the multiplication of the total livestock herd by the average forage consumption per livestock unit (10 kg of dry matter per day; Krausmann et al. 2008). In this study, the word "livestock" refers to bovine species such as cattle and buffaloes, which represent by far the majority of the grazing livestock herd in the Legal Amazon. By overlaying the initial land-use map (appendix A) and the map of livestock density (LD) by FAO (FAO 2007a), we estimated that approximately $14 \%$ of the Legal Amazon livestock herd is located in PM pastures. Therefore, in the simulations in which PM pastures persist in the future (see next section), we assign a constant value of $14 \%$ of the total livestock herd to be 
Earth Interactions • Volume 15 (2011) - Paper No. 16 • Page 8

allocated in PM pastures (and $86 \%$ in WM pastures). A total of $95 \%$ of the livestock feed demand is fulfilled by forage from pastures, and the rest is from feed grains or crop residues (Krausmann et al. 2008). If forage demand is higher than supply, then new pasture cells are allocated, starting from grid cells with the highest suitability for grazing until demand is fulfilled. Average LD is calculated by dividing the livestock herd by the pasture area. Allocation of land-use activities follows the hierarchical order: settlement, crop cultivation, well-managed grazing, and poorly managed grazing. Only one land-use type can occur in a grid cell.

\subsection{Input data and modeling protocol}

LandSHIFT is initialized with a land-use/land-cover map for the year 2006, a map of population density (Goldewijk 2005), and national statistics of crop production and livestock herd (IBGE 2010). Socioeconomic projections include future demands for food (Rosegrant et al. 2008) and population growth (Hughes 1999) under a baseline scenario.

\subsubsection{Population and economics}

The human population in the study area increases from 24.2 million people in 2006 to 32.6 million people in 2050, representing an average annual growth of $0.8 \% \mathrm{yr}^{-1}$. Brazil GDP increases from $\$ 954 \times 10^{9}$ U.S. dollars (USD; year 2000 dollars) in 2006 to $\$ 7,226 \times 10^{9}$ USD (year 2000 dollars) in 2050, with an average growth rate of $4.42 \% \mathrm{yr}^{-1}$, which is comparable to those projected by the Intergovernmental Panel on Climate Change (IPCC) SRES A2 and A1 for Latin America (3.8\% and 5.5\% $\mathrm{yr}^{-1}$, respectively) (Nakicenovic and Swart 2000).

\subsubsection{Agricultural production}

The projections of IMPACT consider price effects that come from dynamics on both the supply and demand side of food and feed commodities (Rosegrant et al. 2008). Prices are calculated internally in IMPACT, to satisfy a market-clearing condition: that is, when world supply and demand for agricultural products are in balance and world net trade equals zero (Rosegrant et al. 2008). The IMPACT baseline scenario projects that the demand for agricultural products, especially cereals and animal products, will increase worldwide until 2050 driven by population growth and also by other factors like increasing demands for crop-based biofuels. Importantly, it projects considerable increases in the annual demand for meat in East Asia (+55\%), South Asia (+133\%), and Sub-Saharan Africa (+63\%) and little changes in Latin America and other parts of the world (for region definition, see Rosegrant et al. 2008). Such an increase in the demand for food products pushes global food prices up, with beef prices increasing from $\$ 1,912 \mathrm{USD} \mathrm{Mg}^{-1}$ in 2000 to $\$ 2,504 \mathrm{USD} \mathrm{Mg}^{-1}$ in $2050(+30 \%)$, rice prices increasing from $\$ 184$ to $\$ 323 \mathrm{USD} \mathrm{Mg}^{-1}$ ( $+75 \%$ ), maize prices increasing from $\$ 87$ to $\$ 132 \mathrm{USD} \mathrm{Mg}^{-1}$ $(+52 \%)$, and soybean prices increasing from $\$ 205$ to $\$ 328 \mathrm{USD} \mathrm{Mg}^{-1}(+60 \%)$. The production (supply) of agricultural goods also increases worldwide, with a remarkable increase in the production of cereals in North America, Europe, and 
Earth Interactions • Volume 15 (2011) • Paper No. 16 • Page 9

Table 1. Crop production in 2006 (IBGE 2010), projection for 2050 (Rosegrant et al. 2008), and 2006-50 changes in the Brazilian Legal Amazon.

\begin{tabular}{lccc}
\hline & $2006(\mathrm{Gg})$ & $2050(\mathrm{Gg})$ & $\Delta 2006-50(\%)$ \\
\hline Rice & 2392 & 2138 & -11 \\
Maize & 5757 & 9944 & +73 \\
Other tropical cereals & 294 & 951 & +224 \\
Pulses & 213 & 685 & +222 \\
Tropical roots and tubers & 9591 & 18521 & +93 \\
Annual oil crops (excluding soybean) & 34 & 62 & +84 \\
Soybean & 17788 & 19692 & +11 \\
Sugarcane & 17146 & 14070 & +175 \\
Other crops* & 5567 & 113196 & +153 \\
Total & 58781 & & +93 \\
\hline
\end{tabular}

* Permanent oil crops, fruits, vegetables, fiber crops, coffee, cocoa, and other stimulants.

Central Asia. In terms of livestock production, the largest share of global production $\left(421 \times 10^{6} \mathrm{Mg}\right)^{2}$ in 2050 is in East Asia (33\%), followed by North America and Europe (28\%) and Latin America (11\%). Latin America's livestock product output increases by $180 \%$ over the $2006-50$ period $\left(3.6 \% \mathrm{yr}^{-1}\right)$. A similar growth is also projected for South Asia, although it comprises a smaller share of global production (7\%) in 2050.

Crop production in the Legal Amazon increases by 93\%, with soybean production increasing by $11 \%$ (Table 1). The livestock herd of Legal Amazon grows from 75.7 million head in 2006 to 152.9 million head in 2050, with an average increase of $2.3 \% \mathrm{yr}^{-1}$. This growth rate is far below the average growth of $9.3 \% \mathrm{yr}^{-1}$ observed in the 1974-2006 period in the region (IBGE 2010) and reflects the effect of livestock's own price and the price of competing commodities in the future (shown above). Moreover, it would be too difficult to sustain the high growth observed in the last 30 years in the long term. Official statistics show that livestock growth rate is reducing with years (e.g., 6.1\% $\mathrm{yr}^{-1}$ in the 1990-2006 period) because of, among other factors, an increase in the slaughtering rate (Barreto et al. 2008; Gouvello et al. 2010). More information on the IMPACT baseline scenario can be found in the study by Msangi and Rosegrant (Msangi and Rosegrant 2009).

\subsubsection{Crop/pasture productivity}

Potential crop/grass yields were calculated with the LPJmL model, which simulates global terrestrial vegetation dynamics, agricultural productivity, and the associated carbon and water cycles in a $0.5^{\circ}$ spatial resolution (Sitch et al. 2003; Gerten et al. 2004; Bondeau et al. 2007). The LPJmL model calculations are based on physiological processes such as photosynthesis, autotrophic respiration, evapotranspiration, and effects of soil moisture and drought stress, as well as on plant's functional and allometric rules, phenology, and growth parameterizations. Full model description as well as extensive validation against observed data of sowing dates, fraction of photosynthetically active absorbed radiation, seasonal $\mathrm{CO}_{2}$ flux exchanges, and crop yields can be found in the studies by Bondeau et al. (Bondeau et al. 2007) and Lapola et al. (Lapola et al. 2009b).

\footnotetext{
${ }^{2}$ Production of beef, pork, lamb, and poultry.
} 
Earth Interactions - Volume 15 (2011) • Paper No. 16 • Page 10

Crop yields for the 1990s, used as baseline yields in LandSHIFT, were calculated using the Climate Research Unit-Time Series 2.1 (CRU-TS2.1) climate dataset, a monthly climatology of meteorological variables, and atmospheric $\mathrm{CO}_{2}$ concentration for the 1901-2003 period (Österle et al. 2003; Keeling and Whorf 2010). LPJmL transient simulations are preceded by a $1000-\mathrm{yr}$ spinup period during which the first 30 years of the climate dataset are repeated cyclically to bring all carbon pools into equilibrium. Future crop yields (2036-65 mean) were calculated using the outputs from two IPCC AR4 general circulation models (GCMs), both under the SRES A2 emission scenario: the third climate configuration of the Met Office Unified Model (HadCM3) and the National Center for Atmospheric Research (NCAR) Community Climate System Model, version 3 (CCSM3) (Meehl et al. 2007). Climate anomalies (Figure 1) were defined as the differences from the 1961-90 mean of the CRU-TS2.1 dataset. Besides being among the GCMs that best represent the current climate over the Amazon (Li et al. 2006), these two GCMs project highly distinct climatic changes for the twenty-first century in the Amazon. HadCM3 projects an average increase of $3.8^{\circ} \mathrm{C}$ and a $30 \%$ decrease in precipitation over the Legal Amazon in the 2036-65 period (hereafter the severe climate change scenario), whereas CCSM3 projects a smaller temperature increase of $1.8^{\circ} \mathrm{C}$ and no changes in average precipitation (hereafter the moderate climate change scenario). Atmospheric $\mathrm{CO}_{2}$ concentration increases from an average $333 \mathrm{ppmv}$ in the 1961-90 period to $537 \mathrm{ppmv}$ in the 2036-65 period. Improvement of yields through technological changes (e.g., plant breeding, increased use of fertilizer, and irrigation) are not considered in our simulations.

\subsubsection{Experimental design}

The effects of $\mathrm{CO}_{2}$ fertilization on crop productivity are still poorly understood, especially in the tropics, and seem to be overestimated by most vegetation models currently available, including LPJmL (Slingo et al. 2005; Ainsworth and Long 2005). Therefore, we consider the upper limit of the effect of climate change on crop/grass productivity to be the HadCM3 climate scenario without the effects of $\mathrm{CO}_{2}$ fertilization. The lower limit is then considered to be the yields calculated with CCSM3 climate and with the $\mathrm{CO}_{2}$ fertilization effect. Four scenario variations are modeled with LandSHIFT, all of them with road paving and IMPACT projections on crop and livestock production for 2050:

(i) $\mathrm{CCSM} 3$ climate $+\mathrm{CO}_{2}$ fertilization (moderate-BAU);

(ii) $\mathrm{HadCM} 3$ climate, no $\mathrm{CO}_{2}$ fertilization (severe-BAU);

(iii) $\mathrm{CCSM} 3$ climate $+\mathrm{CO}_{2}$ fertilization, suppression of PM pastures, and deforestation of the Amazon (Cerrado) gradually reduced to zero until 2020 (2025) (moderate-CONSERV); and

(iv) HadCM3 climate, no $\mathrm{CO}_{2}$ fertilization, suppression of PM pastures, and deforestation of the Amazon (Cerrado) gradually reduced to zero until 2020 (2025) (severe-CONSERV).

PM pastures are gradually replaced by WM pastures until 2025 in the variations in which a suppression of PM pastures is assumed. The intensification of grazing needed to meet the feed demands of future livestock production in variations moderate-CONSERV and severe-CONSERV is determined by increasing the 

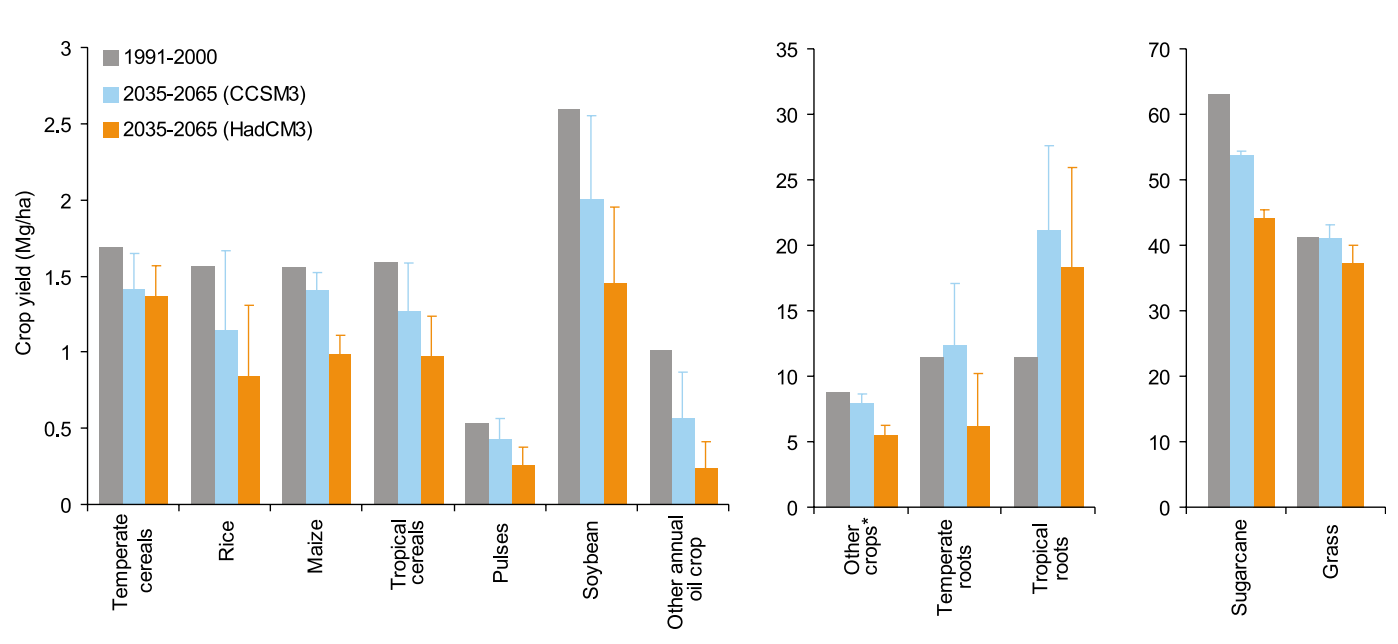

Figure 3. Crop and grass average yield (fresh matter) observed in the 1990s and projections for the 2036-65 period under a moderate climate change scenario (CCSM3, SRES A2) and under a severe climate change scenario (HadCM3, SRES A2) in the Brazilian Legal Amazon. Top whiskers denote projections in which the $\mathrm{CO}_{2}$ fertilization effect influences crop/grass yields. Grass (pasture) comprises predominantly $\mathrm{C}_{4}$ grass. The other crops category includes permanent oil crops, fruits, vegetables, and stimulants (average yield).

grazing efficiency $g_{e}$ factor to the level at which demands are met, though keeping $g_{e}$ below the maximum reported value of 0.7 (Difante et al. 2009). The definition of deforestation used within LandSHIFT refers only to primary vegetation, and it means that all the vegetation of a given grid cell (forest or savanna) is cleared.

\section{Results}

\subsection{Potential yields}

Figure 3 shows the simulated changes in crop/grass yields relative to their values in the 1990s. Average (between all crop/grass types) yield changes range from $-11 \%$ with $\mathrm{HadCM} 3$ climate to $+14 \%$ with CCSM3 climate when the $\mathrm{CO}_{2}$ fertilization effect is considered. However, crop yields are $-31 \%$ (HadCM3) to $-8 \%$ (CCSM3) lower compared to the 1990s if we consider that the $\mathrm{CO}_{2}$ fertilization effect will have no influence on future crop yields. The reductions by $44 \%$ and $10 \%$ in the yields of soybean and grassland, respectively, under the severe-BAU scenario are particularly relevant for the Legal Amazon (besides considerable reduction in the yields of maize, rice, and other crops under that scenario). Soybean yield decreases by $1.8 \%$ and grass yield increases by $4.5 \%$ in the moderate-BAU scenario. Tropical roots functional type (cassava) is the only crop that experiences an increase of yields in every scenario because, in LPJmL, this crop type benefits from the increase in temperature. In general, the most pronounced yield reductions are found in the northern portion of the Legal Amazon (especially in Pará and Maranhão) because both HadCM3 and CCSM3 climate model project reductions in precipitation in that region (Figure 1). 

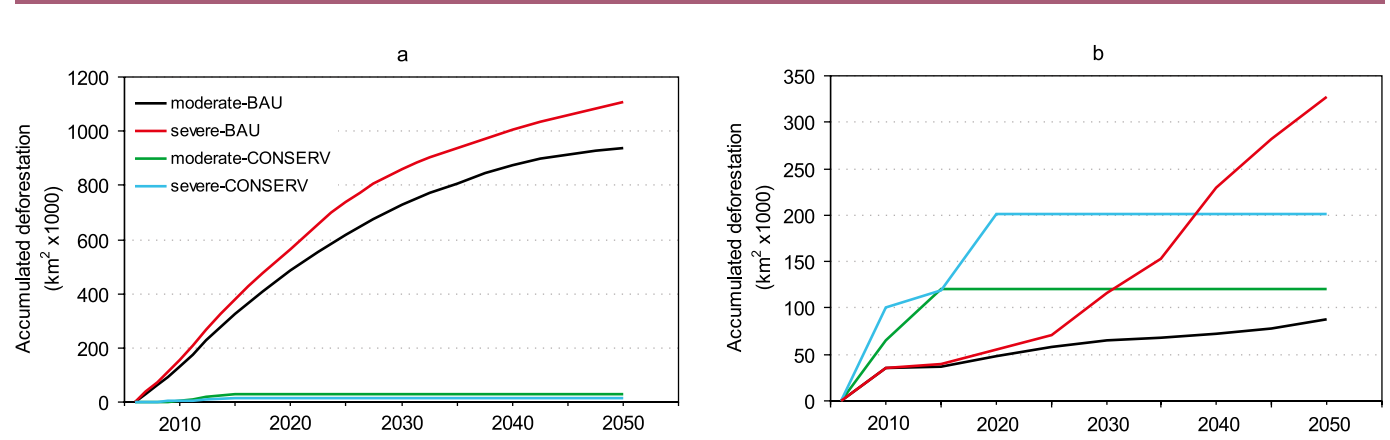

Figure 4. Accumulated deforestation (2006-50) of (a) the Amazon and (b) Cerrado under different scenarios of climate change and conservation in the Brazilian Legal Amazon.

\subsection{Land-use change with business as usual}

Under a moderate climate change scenario (and ignoring the target of halting deforestation in the Amazon) deforestation of the Brazilian Amazon would amount to $928000 \mathrm{~km}^{2}$ by $2050\left(20173 \mathrm{~km}^{2} \mathrm{yr}^{-1}\right.$ in the $2006-50$ period) in our simulations (Figure 4a and Table 2). On the other hand, under a severe climate change scenario (severe-BAU) the forest would be reduced by $1109000 \mathrm{~km}^{2}\left(24108 \mathrm{~km}^{2} \mathrm{yr}^{-1}\right)$. Therefore, in these BAU simulations Amazon deforestation would be $20 \%$ higher under severe climate change compared to a scenario of moderate climate change. Deforestation of the Cerrado simulated by LandSHIFT would amount to $88000 \mathrm{~km}^{2}$ $\left(1913 \mathrm{~km}^{2} \mathrm{yr}^{-1}\right)$ and $328000 \mathrm{~km}^{2}\left(7130 \mathrm{~km}^{2} \mathrm{yr}^{-1}\right)$ under the moderate-BAU and severe-BAU climate change scenarios, respectively (Figure $4 \mathrm{~b}$ and Table 2). Thus, in these BAU simulations deforestation of the Cerrado would be $273 \%$ higher with severe climate change compared to a scenario with moderate climate change.

Altogether, crops would need a $45 \%$ larger area under the severe scenario compared to the moderate scenario to meet the 2050 demands projected by IMPACT for the Amazon. Soybean alone would occupy a 49\% larger area in the severe scenario compared to the moderate scenario (94000 versus $\left.63000 \mathrm{~km}^{2}\right)$. WM pasture (PM pasture) would have its area increased by $615000(311000) \mathrm{km}^{2}$ in the moderate scenario and by $838000(423000) \mathrm{km}^{2}$ in the severe scenario. Difference in total area of both types of pastures between the climate scenarios would be of $18 \%$. LD decreases in both climate scenarios, although this decrease is more pronounced in the severe climate change scenario. That is because, even though average grass productivity increases from 2006 to 2050 in the moderateBAU, it decreases punctually in the regions where new pastures are established until 2050, north and northeast Legal Amazon. Abandoned area increases by 16000 and $9000 \mathrm{~km}^{2}$ in the moderate and severe climate change scenarios, respectively (Table 2), because of a shift in cropland location driven by local climate change (e.g., reduction in precipitation in western Mato Grosso with CCSM3 causes some soybean fields to shift to southeastern Mato Grosso).

Most of the deforestation would still occur in the southern and eastern Amazon and along the paved highways (Figure 5), which is explained by the weights $w_{i}$ given to the $p_{i}$ factors shown in Figure 2. Cropland expansion would take place 


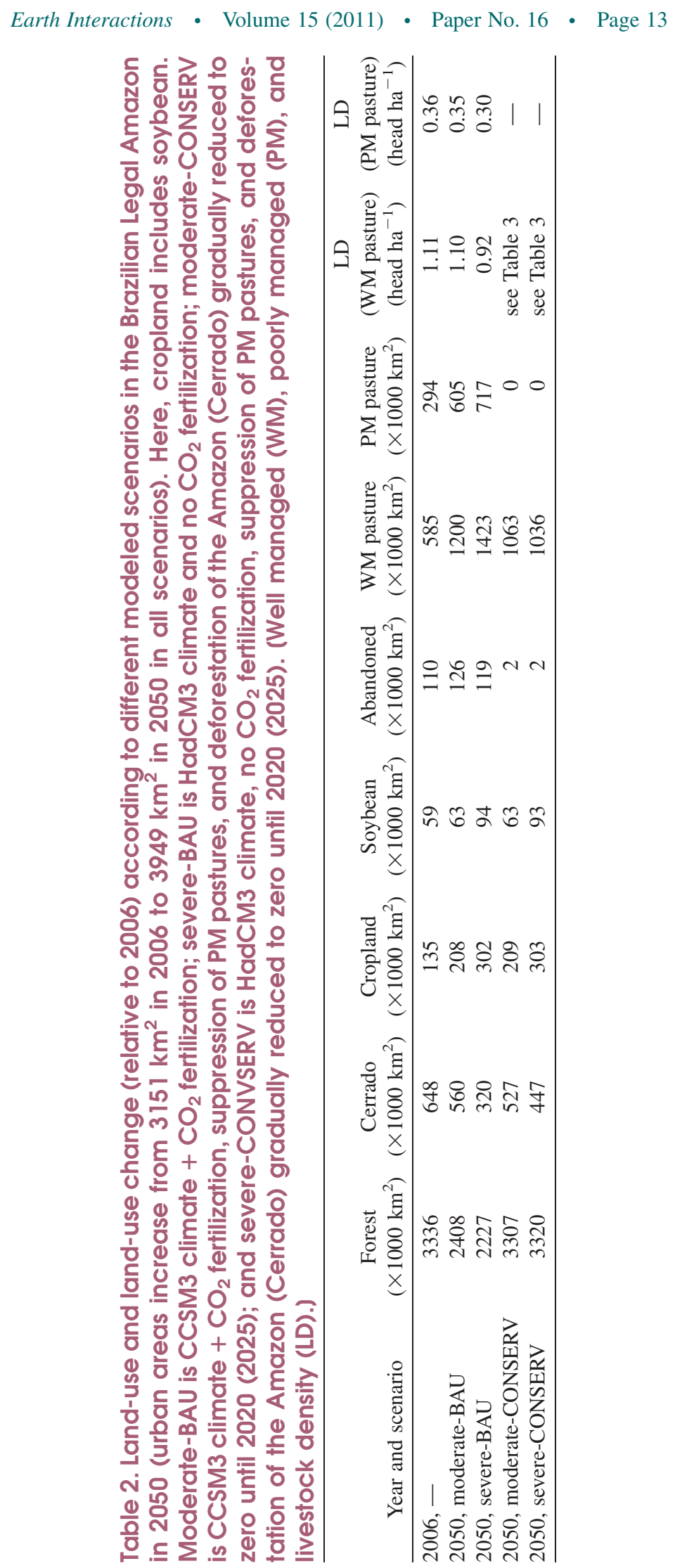




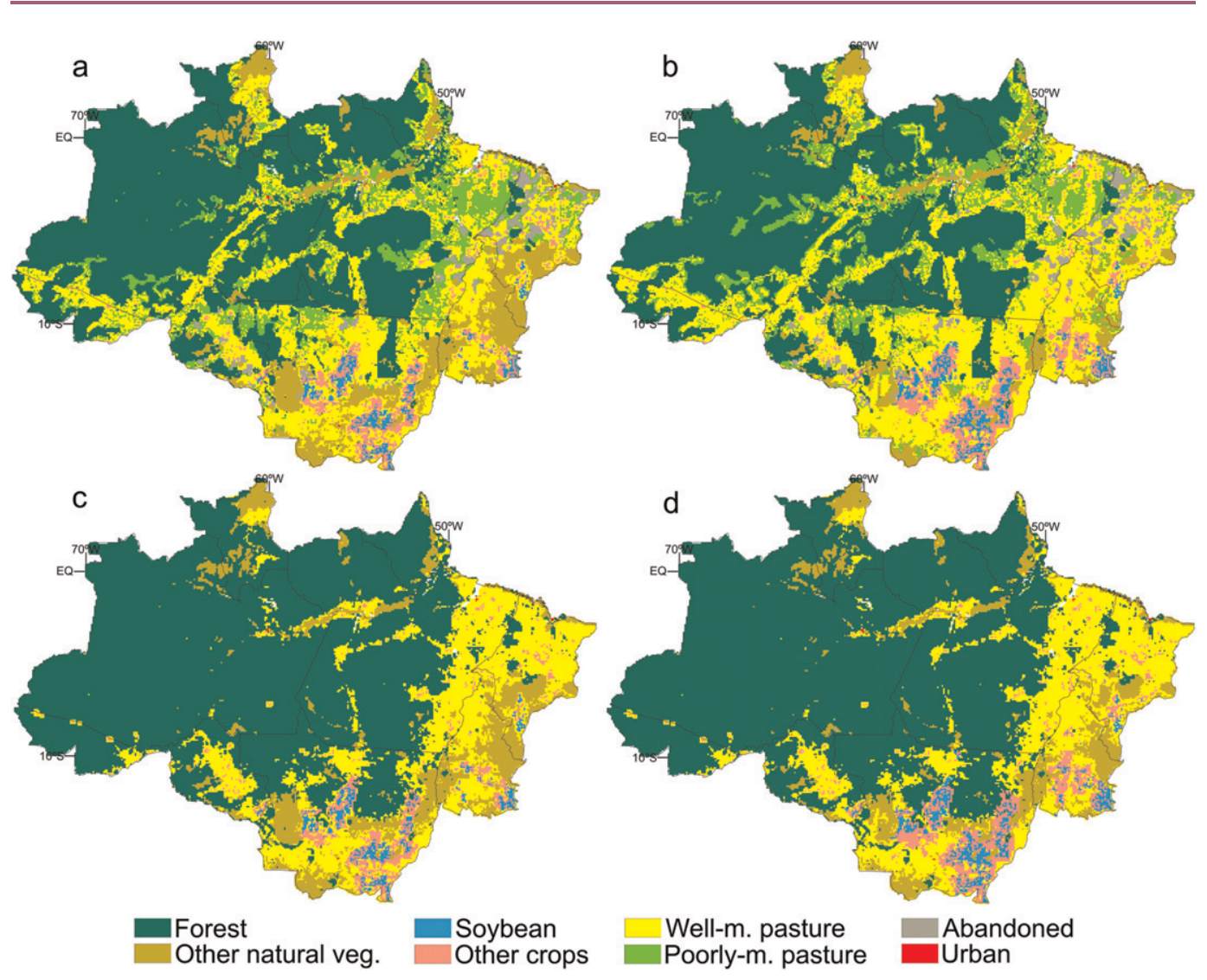

Figure 5. Modeled land use and land cover in the Brazilian Legal Amazon in 2050 under (a), (c) moderate (CCSM3 SRES A2 with $\mathrm{CO}_{2}$ fertilization effect) and (b),(d) severe (HadCM3 SRES A2 without $\mathrm{CO}_{2}$ fertilization effect) climate change scenarios and under two deforestation-trend scenarios, (a),(b) BAU and (c),(d) CONSERV (deforestation of the Amazon (Cerrado) is gradually reduced to zero until 2020 (2025) and there is suppression of poorly managed pastures).

mostly in Mato Grosso and Tocantins. WM pastures would be widespread along the deforestation arc. Because PM pasture is the last in the hierarchical allocation of major land-use activities in LandSHIFT, this land-use type is relegated to more remote and less productive areas. Figure 6 highlights how different climate change scenarios could result in distinct deforestation patterns, impacting both the extent and location of future LUCC. Pastures expand deeper into the western Amazon forest and especially in the Cerrado in the severe scenario compared to the moderate one because of the pronounced decrease in precipitation projected by HadCM3 in northern Legal Amazon.

\subsection{Land-use change with the end of deforestation}

From 2006 to 2050 Amazon deforestation would amount to $29000 \mathrm{~km}^{2}$ $\left(2230 \mathrm{~km}^{2} \mathrm{yr}^{-1}\right)$ and $16000 \mathrm{~km}^{2}\left(1230 \mathrm{~km}^{2} \mathrm{yr}^{-1}\right)$ under moderate-CONSERV 


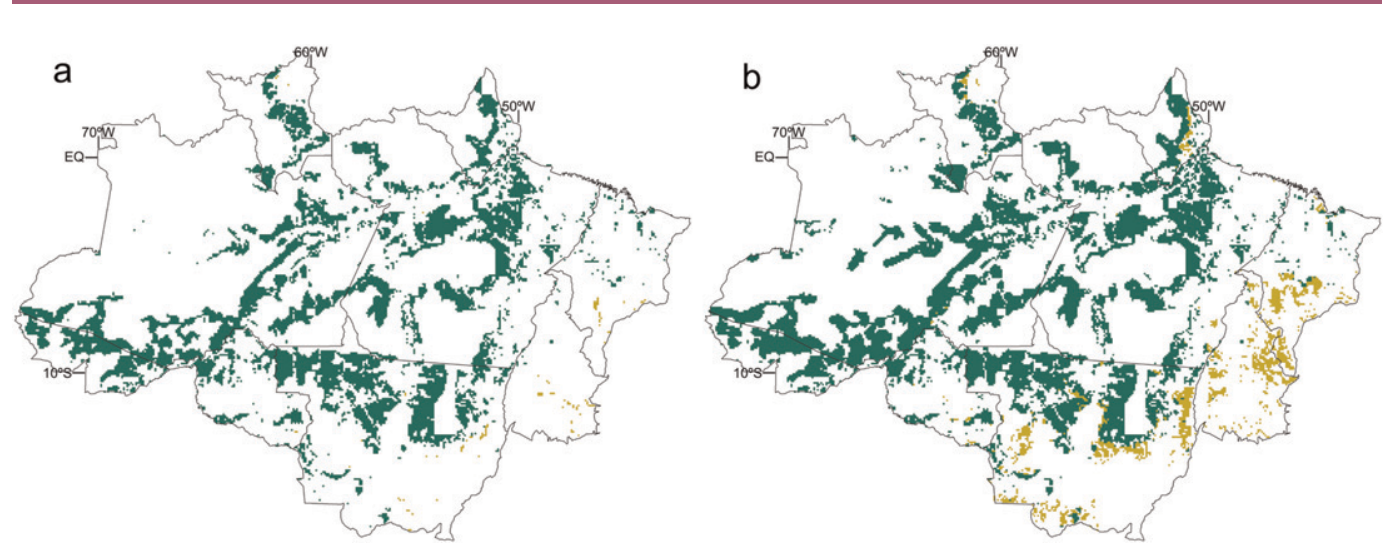

Figure 6. Avoided deforestation of the Brazilian Amazon (green) and Cerrado (yellow) as obtained by comparing the scenario CONSERV (deforestation of the Amazon (Cerrado) is gradually reduced to zero until 2020 (2025) and there is suppression of poorly managed pastures) with BAU, under two scenarios of climate change, (a) moderate (CCSM3 SRES A2 with $\mathrm{CO}_{2}$ fertilization effect) and (b) severe (HadCM3 SRES A2 without $\mathrm{CO}_{2}$ fertilization effect).

and severe-CONSERV scenarios, respectively, before it ends by 2020 (Figure 4a and Table 2). On the other hand, the Cerrado loses $121000 \mathrm{~km}^{2}\left(9307 \mathrm{~km}^{2} \mathrm{yr}^{-1}\right)$ and $201000 \mathrm{~km}^{2}\left(15461 \mathrm{~km}^{2} \mathrm{yr}^{-1}\right)$ of its native vegetation by 2025 in the moderateCONSERV and severe-CONSERV scenarios, respectively (Figure 4b and Table 2). Halting Amazon deforestation by 2020 but still allowing deforestation of the Cerrado until 2025 explains these highly different deforestation rates when compared to the BAU scenarios.

Future cropland area would be roughly the same as in the BAU scenarios because crops have priority over pastures in LandSHIFT in this study; that is, crops are allowed to displace pastures. Therefore, the area of pasture would increase in approximately $171000 \mathrm{~km}^{2}$, by replacing natural vegetation, specifically by occupying PM pastures and abandoned areas (Figure 5). Then, at this point, two options are considered here to conciliate agricultural production and conservation targets in the Legal Amazon (Table 3):

(i) Livestock production is reduced; that is, from $26 \%$ (moderate-CONSERV) to $40 \%$ (severe-CONSERV) of the Legal Amazon livestock production projected for the year 2050 cannot be produced there.

(ii) Livestock production is ensured/kept up with the intensification of livestock in the Legal Amazon. In that case, livestock density needs to roughly double from 0.74 head per hectare (average between PM and WM pastures) in 2006 to $\sim 1.46$ head per hectare (1.44 head per hectare in moderate-CONSERV and 1.48 head per hectare in severe-CONSERV). Grazing efficiency $g_{e}$ is increased to 0.47 , a value still far from the maximum of 0.7 reported by Difante et al. (Difante et al. 2009) under rotational stocking management.

Figure 5 shows the land-use pattern in 2050 in the moderate-CONSERV and severeCONSERV scenarios. Some deforestation of the Amazon is projected in northeast 
Earth Interactions V Volume 15 (2011) • Paper No. 16 • Page 16

Table 3. Livestock production and correspondent livestock density in the Brazilian Legal Amazon in $\mathbf{2 0 5 0}$ with the end of deforestation in the Amazon (Cerrado) by 2020 (2025). Moderate-CONSERV is CCSM3 climate $+\mathrm{CO}_{2}$ fertilization, suppression of poorly managed pastures, and deforestation of the Amazon (Cerrado) gradually reduced to zero until 2020 (2025); severe-CONSERV is HadCM3 climate, no $\mathrm{CO}_{2}$ fertilization, suppression of poorly managed pastures, and deforestation of the Amazon (Cerrado) gradually reduced to zero until 2020 (2025).

\begin{tabular}{lccc}
\hline \multicolumn{1}{c}{ Scenario } & $\begin{array}{c}\text { Fulfillment of } \\
\text { IMPACT projected } \\
\text { livestock production }(\%)\end{array}$ & $\begin{array}{c}\text { Livestock } \\
\text { herd }\left(\times 10^{6} \text { head }\right)\end{array}$ & $\begin{array}{c}\text { Livestock density } \\
\left(\text { head ha }^{-1}\right)\end{array}$ \\
\hline Moderate-CONSERV & 74 & 113.1 & 1.06 \\
Moderate-CONSERV & 100 & 152.9 & 1.44 \\
Severe-CONSERV & 60 & 91.7 & 0.88 \\
Severe-CONSERV & 100 & 152.9 & 1.48 \\
Average & 67 & 102.4 & 0.97 \\
Average & 100 & 152.9 & 1.46 \\
\hline
\end{tabular}

Pará and along the highways BR-163 in Mato Grosso and BR-364 in Acre. Most of the deforestation of the Cerrado takes place in Maranhão and Tocantins in areas that are not specified as conservation units, and it is more pronounced in severeCONSERV than in moderate-CONSERV. Compared to BAU scenarios, there would be an avoided deforestation of $899000 \mathrm{~km}^{2}$ of Amazon forest in the moderateCONSERV climate scenario and of $1093000 \mathrm{~km}^{2}$ in the severe-CONSERV scenario. In the Cerrado, there would be an additional deforestation of $33000 \mathrm{~km}^{2}$ in the moderate-CONSERV scenario and an avoided deforestation of $120000 \mathrm{~km}^{2}$ in the severe-CONSERV scenario (Figure 6).

\section{Discussion}

From our simulations, we can infer that in the Legal Amazon,

- Future climate change may influence LUCC in ways that have previously remained unexplored. Severe climate change in some regions can shift the deforestation frontier. For example, the harsh climate projected by HadCM3 in central and eastern Amazon increases human pressure in the Cerrado and western Amazon.

- Ambitious conservation targets and increased agricultural production can be conciliated even under a scenario of severe climate change, but it will require either a more intensive use of the land or a slowdown in the growing production of meat.

These two major findings are discussed below.

\subsection{Climate change effects on land use}

There is now extensive documentation about the impacts of regional or continental extreme climatic events on agriculture and livestock production. Excellent examples are the hot summer of 1972 in the southwest of the former Soviet Union and its consequences in world cereal markets (Dronin and Bellinger 2005); the record yield drops and livestock stress in Europe during the anomalous heat in the 
summer of 2003 (UNEP 2004); the 2005 drought in the Amazon and associated agricultural losses in many parts of Brazil (Lenton et al. 2009); and several studies on the impacts of the El Niño-Southern Oscillation on crop/pasture productivity and food security in the Amazon (Moran et al. 2006; Brondizio and Moran 2008), in Indonesia (Keil et al. 2008), or worldwide (Ferris 1999). Nonetheless, currently such climatic events have a relatively long return interval [El Niño: $\sim 7 \mathrm{yr}$ (Cobb et al. 2003); 2005-like drought: 20 years (Cox et al. 2008)] and are not yet the climatic norm, as, for example, would be the case of the permanent El Niño events projected by HadCM3. One of the single documented references to recent longterm climate change and its effects on yields and LUCC is the prolonged drier conditions found in the Sahel from the late 1960s until the early 1990s which caused the abandonment of crop and grazing fields, besides massive migration and countless hunger- and battle-related deaths (Kandji et al. 2006; Burke et al. 2009). However, most of the examples of long-term climate change impacts on LUCC stem from archeological/historical records, as is the case for the theory of the collapse of the Maya in the Yucatán Peninsula in the late tenth century (Turner et al. 2003) or the effects of the onset of the Little Ice Age (sixteenth century) on the agriculture of the Iberian Peninsula (Puigdefábregas 1998).

These catastrophic experiences reveal that the impacts of climate change on LUCC are always, though not solely, mediated by changes in crop/grass productivity, which is the way LUCC is affected by climate in this study. In view of that, we can consider the method used here for assessing the impacts of climate change on LUCC as reasonable, even though it does not consider other ways in which climate change could indirectly affect LUCC in the Legal Amazon. Difficulties for navigation if the level of rivers is too low, decrease of fish stocks (which is one of the main sources of protein of the Amazonians), spread of diseases, potable water shortage, and higher frequency of floods and fires-all these examples represent pathways through which climate change could affect farmers' and other people's living conditions and, consequently, LUCC in the region.

The simulated range of changes in crop/grass productivity lies within the range projected in other studies for Brazil (Assad and Pinto 2008; Lobell et al. 2008) and the whole globe (Tebaldi and Lobell 2008). That is particularly true for the projections in which the $\mathrm{CO}_{2}$ fertilization effect does affect crop yields in the future. On the other hand, LPJmL yield projections with HadCM3 climate and no $\mathrm{CO}_{2}$ fertilization are much lower than what has been projected in the studies mentioned above but should not be considered as less probable because the uncertainties regarding the effects of rising $\mathrm{CO}_{2}$ on future crop yields are still large (Ainsworth and Long 2005; Long et al. 2006; Lobell and Field 2008). The pronounced decrease in the yields of soybean, slight decrease of maize and rice, as well as the increase of cassava yields are particularly in agreement with the projections by Assad and Pinto (Assad and Pinto 2008), using a regional climate model for entire Brazil. Nevertheless, the authors of that study point out a reduction of up to $25 \%$ of pasture productivity (for entire Brazil) as compared to the $10 \%$ projected with LPJmL-HadCM3 for the Legal Amazon.

Although in this study we calculate the LUCC resulting from yield changes with the HadCM3 climate (Figures 5b,d), we believe it is unlikely that in reality crop cultivation would continue after such a reduction of yields, especially in large-scale farming systems. It is more reasonable to think that such decreasing yields would, 
Earth Interactions - Volume 15 (2011) • Paper No. 16 • Page 18

in the long term, reduce the profitability of agriculture in the region. That could lead in turn to an encroachment of the cultivated area and certainly to a shift of that agricultural production to other more lucrative areas of Brazil (probably generating more deforestation of the Cerrado as suggested by our results and the study by Gouvello et al. 2010) or even to other parts of the world. This might in turn have serious consequences for the economy of the Legal Amazon and for the food security of its inhabitants.

Technological improvements of yields are, on purpose, not considered in our simulations so one can regard the projections shown in Figure 3, especially those calculated with HadCM3 climate, as an outlook on the magnitude of adaptation needed by the agriculture of the Legal Amazon over the next decades. So, for example, to avoid the soybean yield reduction caused by an extreme climate change scenario (i.e., to keep soybean yields at their current values at least), a yield increment rate of $23 \mathrm{~kg} \mathrm{ha}^{-1} \mathrm{yr}^{-1}$ would be needed until 2050, which is far lower than the soybean yield enhancement rate of $39 \mathrm{~kg} \mathrm{ha}^{-1} \mathrm{yr}^{-1}$ observed in the last two decades in Brazil (FAO 2010; Lapola et al. 2010). For maize, this yield adaptation would be $11 \mathrm{~kg} \mathrm{ha}^{-1} \mathrm{yr}^{-1}$, compared to $78 \mathrm{~kg} \mathrm{ha}^{-1} \mathrm{yr}^{-1}$ yield enhancement observed in the last two decades in Brazil (FAO 2010; Lapola et al. 2010). This adaptation of cropping and livestock systems could come in the form of better management of water resources, change in sowing dates, development of heat-tolerant crop varieties, infrastructure to minimize heat-stress-related reductions of livestock productivity, or even altering the location of cropping/livestock activities (Howden et al. 2007). However, all these actions would obviously demand financial investments. As a consequence, adaptation seems more feasible to large-scale farmers than for smallholder or subsistence farmers because of the former's easier access to credit. A recent survey revealed that, although smallholder agriculture occupies only $24 \%$ of the total farmed area in Brazil, it is responsible for $87 \%$ of the national production of cassava, $70 \%$ of dry beans, $46 \%$ of maize, $36 \%$ of rice, and $58 \%$ of milk (IBGE 2009). As presumed from our results, this agricultural production (its share in the Legal Amazon) might be compromised in the future assuming no intervention and/or support from the government or other bodies to develop adaptation strategies for the sector (Morton 2007). Such a strategy should take into account the sociocultural and environmental diversity of the Amazonian small-scale farmers and, importantly, institutionalize the translation of large-scale projections, like the one in this study, into local actions (Brondizio and Moran 2008).

\subsection{The end of deforestation and land use}

Our results also show that a combination of ambitious conservation targets (in the way suggested by Nepstad et al. 2009) with increased agricultural production is feasible even under a scenario of severe climate change. However, adaptation of agriculture, especially the intensification of cattle ranching, which is the main land use in Legal Amazon, is a sine qua non condition to achieve both targets. Brazil's recent economic growth has boosted people's monetary access to meat, and the country today is the fourth biggest consumer of meat per capita in the world (Barreto et al. 2008; Friends of the Earth 2009). Considering these current trends of 
Earth Interactions - Volume 15 (2011) • Paper No. 16 • Page 19

changes in life style, it seems more likely that the mentioned conservation targets might be achieved via intensification of livestock production rather than via reduction of livestock production and consequent meat consumption.

It is well known that the oxisols and ultisols of the Amazon, dominant in over $75 \%$ of the basin, make it difficult to keep a high productivity of pastures for more than $\sim 5$ years without active management (Walker et al. 2000). However, other factors such as land tenure (e.g., in many cases LD is kept at a minimum level only to guarantee ownership over public land), and ongoing policies of "perverse" subsidies (e.g., animal acquisition is heavily subsidized in Brazilian cattle ranching but nearly no incentives are provided specifically for the recovery of degraded pastures and intensification of grazing) also have a decisive influence on the widespread low LD across the Legal Amazon (Hecht 1985; Fearnside 2002; Nepstad et al. 2006; Friends of the Earth 2009). As discussed by Lapola et al. (Lapola et al. 2010), an increase in livestock density in the Legal Amazon, such as the +0.72 head per hectare proposed here, is perfectly possible from a biophysical point of view with the enhancement of grass productivity and adoption of some simple management practices (FAO 2007b; Assad and Pinto 2008). Nevertheless, this intensification seems to be impossible without a concerted effort in terms of providing adequate subsidies (Friends of the Earth 2009), increasing land tenure in the region (Fearnside 2008) and excluding deforesters from the livestock supply chain (Nepstad et al. 2009).

Particularly for the Cerrado, this study calls attention for the lack of protected areas of that habitat in the Legal Amazon (viz., in east Mato Grosso, northeast Tocantins, and south Maranhão), and the potential consequences this might have in the future in case we have the climate projected by HadCM3 by 2050. Likewise, it suggests that stopping deforestation concomitantly in the Amazon and Cerrado might be important to prevent the end of deforestation in the Amazon forest causing an escalation of deforestation in this highly biodiverse but threatened savanna (currently $39 \%$ of the native cover of Cerrado has already been deforested compared to $15 \%$ of the Amazon forest; Sano et al. 2007; PRODES 2009).

\subsection{Caveats and future research}

The main caveat of our simulation is that there are no feedbacks between the models comprised in our framework. Without a real coupling between the models, we are unable to assess, for example, the feedbacks between climate change, crop yields, and crop market prices. In this study, we consider both projections of crop prices and production as not dependent on climate or conservation targets. However, it is probable that a future El Niño-like climate (e.g., projected by HadCM3) would drive crop prices up in the Legal Amazon, which in the long term could lead to a shift of the regional agricultural production to other parts of Brazil or even of the world. That could in turn lead to changes in the regional economy and compromise the local provision of food. Likewise, it could also occur that the agricultural production projected by IMPACT is reduced over time with the establishment of stricter conservation targets (e.g., those suggested by Nepstad et al. 2009) via constraints in the availability of arable land.

An improved and fully coupled modeling framework could also help understanding other key questions about the Amazon system. For example, what would 
Earth Interactions - Volume 15 (2011) • Paper No. 16 • Page 20

be the impacts of a climate-driven forest dieback (Cox et al. 2004) on the deforestation rates and land-use pattern in the Amazon? How would year-to-year climate variability influence future LUCC and food security? What are the probabilities of the impacts (e.g., assessed with ensemble runs)? These questions remain to be pursued.

\section{Conclusions}

The modeling exercise presented in this paper demonstrates some plausible impacts that climate change and conservation strategies might have on land use in the Brazilian Amazon. Without any adaptation, climate change would exert a critical impact on the productivity of Amazonian crops: for example, the 44\% reduction in soybean yields in the worst climate scenario. Moreover, the severity of climate change may influence the location and magnitude of future LUCC. Our study suggests that agriculture, especially cattle ranching, will need to adapt to these two upcoming shifts in the Amazonian system (climate change and the end of deforestation). Importantly, however, it also suggests that both the identification of impacts and the adaptation to them should be tackled in a multidisciplinary and integrated manner, considering conservation strategies and projections on population growth, changes in lifestyle, and agricultural production.

Acknowledgments. We are grateful to C. Koelking and three anonymous reviewers for their helpful comments on the manuscript. Thanks also to U. Heyder for preparing the input climate data for LPJmL. D. M. Lapola was supported by the International Max Planck Research School on Earth System Modelling, Hamburg, Germany. R. Silvestrini and B. S. Soares-Filho are supported by Brazil's Conselho Nacional de Desenvolvimento Científico e Tecnológico, The Gordon and Betty Moore Foundation, and the Climate and Land Use Alliance.

\section{Appendix A}

\section{Land-Use Maps of the Legal Amazon in 2001 and 2006}

For the production of the two "observed" land-use maps employed in this study (for model initialization and/or validation), we used land-cover maps of the Legal Amazon in 2001 and 2006, produced by using Monitoramento da Floresta Amazônica por Satélite (PRODES) satellite data (PRODES 2009), a 2000 vegetation map of South America (Eva et al. 2004), and a classified Moderate Resolution Imaging Spectroradiometer (MODIS) vegetation continuous field (Hansen et al. 2002). The maps' forest category encompasses subtypes such as transitional forest, whereas the category Cerrado encompasses all the phytophysiognomies of the Brazilian savannas (Cerradão, Campo Limpo, etc). These land-cover maps were degraded to the resolution of 5 arc-min and were divided into 32 regions, as suggested by Garcia et al. (Garcia et al. 2007) and Soares-Filho et al. (Soares-Filho et al. 2006). Although these regions did not change over time, this division was used to minimize the erroneous allocation or nonallocation of land uses anywhere in the Legal Amazon (the smaller the region for making the downscaling of census data, the smaller the potential error in determining the location of cropland/pasture within that particular region). Each of these subunits had their own crop and 
pasture area determined from the Instituto Brasileiro de Geografia e Estatística (IBGE) municipal agricultural production database for the given years (IBGE 2010). Because data on pasture area are not available for the year 2001, it was estimated, through linear interpolation, from the 1996 and 2006 data. A total of 13 crop types and 2 pasture types were considered in the confection of the land-use maps. Only areas depicted as deforested or as Cerrado (because land-cover changes of this latter are not tracked by satellites as the deforestation of the Amazon) could have the assignment of crops or pasture. Crops had priority over pasture for occupation of grid cells, whereas only one dominant land-use type can occur in one grid cell. The allocation procedure followed a preference list of grid cells, which was built based on a 2000 map on the geographical distribution of crop/pasture areas, also on 5-arc-min resolution (Monfreda et al. 2008; Ramankutty et al. 2008). Grid cells with higher fraction of a given crop type in the map by Monfreda et al. (Monfreda et al. 2008) had preference for assignment of that crop type in our land-use map. Disambiguation within one crop type (e.g., when the Monfreda et al. map for soybeans had several grid cells with the same area) or between different crop types (i.e., when Monfreda et al. maps for two or more different crop types had exactly the same value in a given grid cell) was performed using a multicriteria analysis (MCA) of slope, potential productivity of the given crop type (or grassland for pasture), distance from settlements, soil type, and distance from paved roads (for data sources, see Soares-Filho et al. 2006). However, this MCA was needed only in a minor fraction $(<1 \%)$ of the grid cells that later were assigned as crop or pasture. Therefore, the maps of Monfreda et al. (for crops) and Ramankutty et al. (for pastures) played the major role in the allocation of land uses in our base maps. Urban areas were assigned to those grid cells having a population density higher than 2000 people per square kilometer (Erb et al. 2007), using the History Database of the Global Environment (HYDE) map of population distribution (Goldewijk 2005), with no distinction between the years 2001 and 2006.

A first assessment of the land-use maps revealed that the area assigned as abandoned was too large (350 $000 \mathrm{~km}^{2}$ in 2001), surpassing any estimate on the extent of land currently abandoned in the Legal Amazon, which ranges from 61000 to $106000 \mathrm{~km}^{2}$ (several datasets analyzed by Campbell et al. 2008). In fact, the very concept of abandoned land is quite variable and can, for example, refer to temporal characteristics (e.g., set aside), soil conditions (e.g., degraded), or management (e.g., poorly managed) of the land use. Here, the land-use type abandoned is considered to be simply land with no occurrence of any other landuse type. Therefore, considering that PRODES provides trustworthy numbers for the extent of the Amazon forest and that the extent of Cerrado in our maps is in fair agreement with latest surveys (Sano et al. 2007) — besides the fact that most of the geographical subunits with abandoned lands did not have Cerrado within it limits (e.g., Paragominas) — we argue that the IBGE data for pasture area in the Legal Amazon might be underestimated, at least in some regions (see Ramankutty et al. 2008). Thus, to correct this discrepancy, after IBGE area requirement for pasture is fulfilled in our maps (i.e., all crop and pasture areas were allocated at this stage), we assign the poorly managed pasture type to all the remaining grid cells that are covered by pasture in Ramankutty et al. (Ramankutty et al. 2008) map and were, until this stage, set as abandoned in our land-use map. That reduces the area of the abandoned land-use type to $102000 \mathrm{~km}^{2}$, in better agreement with data available 


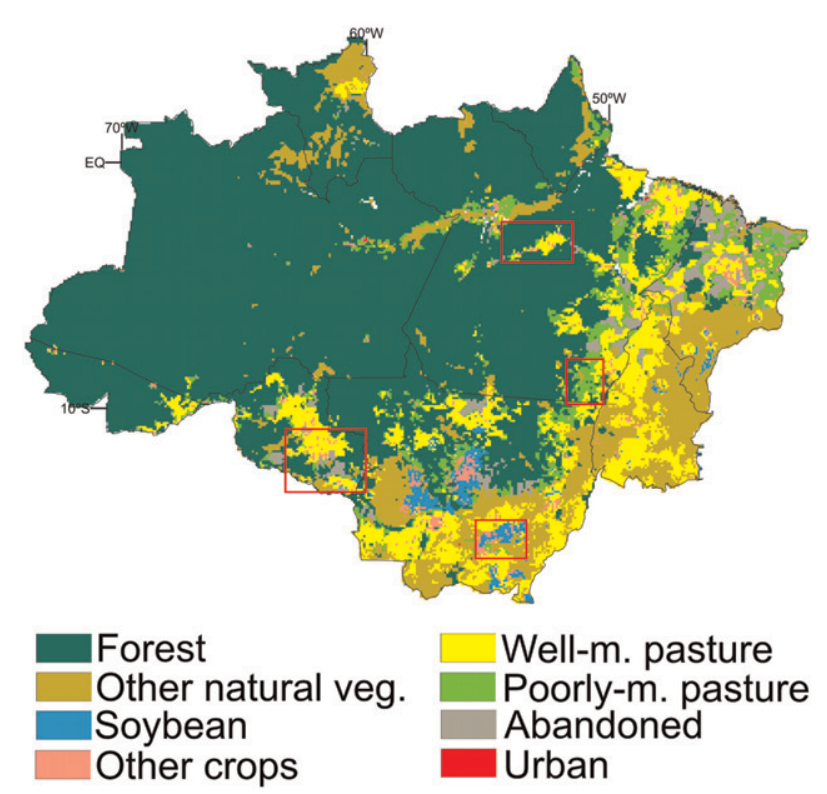

Figure A 1. Land-use and land-cover map of the Brazilian Legall Amazon in 2006. Red squares show regions used in the evaluation of model performance. Here, "m"' stands for "managed."

for comparison. This type of pasture is meant to represent pastures with a lower intensity of use, with lower livestock density (compared to WM pastures), and mixed with degraded/secondary vegetation (cf. locations with INPE 2009). The other type of pasture is then referred to as well-managed pasture. The study by Gouvello et al. (Gouvello et al. 2010) indicates that roughly 30\% of the Legal Amazon pastures are low-productivity pastures, in agreement with the fraction of poorly managed pastures in the 2006 land-use map (Figure A1).

In general, the methods used to obtain these maps are not as comprehensive as, for example, the one used by Cardille and Foley (Cardille and Foley 2003) to produce land-use maps of the Brazilian Amazon for 1980 and 1995 (e.g., our maps have only one land use per grid cell instead of fractional coverage), even though they are in accordance to official statistics (IBGE). Most of all, however, one should consider that the maps presented here were produced as to fit their use in the LandSHIFT model.

\section{Appendix B}

\section{Model Evaluation}

LandSHIFT has been thoroughly evaluated in terms of the quantity of change in other studies (Koch et al. 2008; Schaldach et al. 2011), including a study in which the model was applied for entire Brazil (Lapola et al. 2010). However, the model has not been consistently evaluated in terms of the location of changes mainly because of the lack of independent time series of "observed" land-use maps generated based on the same methodology. Therefore, taking advantage of the two 
independent maps of land use employed here (appendix A), a LandSHIFT run from 2001 to 2006 was performed to evaluate the model performance. The model was initialized with the 2001 land-use map of the Legal Amazon and was driven with reported statistics on crop and livestock production for 2006 (IBGE 2010). Because the 2006 map inherits the spatial pattern of the 2001 map, we assess the spatial fit only between the maps of changes. Thus, the resulting modeled map of LUCC from 2001 to 2006 was compared with the observed map of changes for that period. To reduce the dependency between the datasets used for comparison (the observed maps were used for deriving the $w_{i}$ weights of LandSHIFT), the evaluation was done only in four selected regions of the Legal Amazon (Figure A1). These regions were selected as to cover locations that experienced pronounced deforestation or other LUCC encompassing the three major land-use categories considered here (cropland, WM pasture, and PM pasture) in the 2001-06 period. The four regions and the dominant land-use transitions that were observed from 2001 to 2006 are central Pará (forest to PM pasture, to WM pasture, and to cropland), southeast Pará (forest to PM pasture), south Mato Grosso (Cerrado to cropland), and south Rondônia (PM pasture to WM pasture and forest to cropland). Combined, these four regions represent only $10 \%$ of the area that experienced LUCC in the 2001-06 period and $\sim 4 \%$ of the Legal Amazon.

Both observed and modeled 2001-06 LUCC maps were reclassified into three categories for the comparison: natural vegetation, cropland, and pasture. Conversion from any land use to natural vegetation is excluded from our analysis because LandSHIFT does not simulate natural vegetation regrowth. The maps of changes were subject to the fuzzy vicinity-based comparison method developed by Hagen (Hagen 2003) (K-fuzzy method) and modified by Almeida et al. (Almeida et al. 2008) [reciprocal fuzzy comparison (RFC)]. This method takes into account the nature of LUCC models to justify a vicinity-based comparison (i.e., LUCC location is fuzzy). An exponential decay function is employed to weigh the distance of a cell in one map to its counterpart in the second map. Map comparison is carried out in a two-way manner and at multiple spatial resolutions. However, only the minimum similarity value is used to avoid an artificially high fit, which is characteristic of univocal comparison of random maps. Figure B1 shows the results of this RFC analysis over the four evaluation regions. The model does a reasonable job in capturing the right location of transitions because the average curve reaches up to $60 \%$ of similarity with a search radius of only two grid cells and peaks in $71 \%$ after five grid cells. If the average is weighted by the size of each of the four analyzed regions, then similarity reaches the value of $60 \%$ after three grid cells but peaks have a higher value of $75 \%$ after five grid cells. From the original kappa classification (Monserud and Leemans 1992), a 60\% similarity is classified as a good degree of agreement. Lowest similarity is found in central Pará, because the model does not capture well the transition from forest to WM pasture. On the other hand, the highest fit is found in southeast Pará because the model simulates correctly the forest to PM pasture transition which, according to the maps presented in appendix A, responded for 56\% of the Amazon deforestation in the 2001-06 period.

Cropland is overestimated by $8 \%$, as in the study by Lapola et al. (Lapola et al. 2010) for entire Brazil. The area of pastures was calibrated with the $g_{e}$ factor; therefore, its fit to the observed data is nearly perfect. The modeled rate of Amazon deforestation for 2001-06 is underestimated by $11 \%$ : $20851 \mathrm{~km}^{2} \mathrm{yr}^{-1}$ versus 


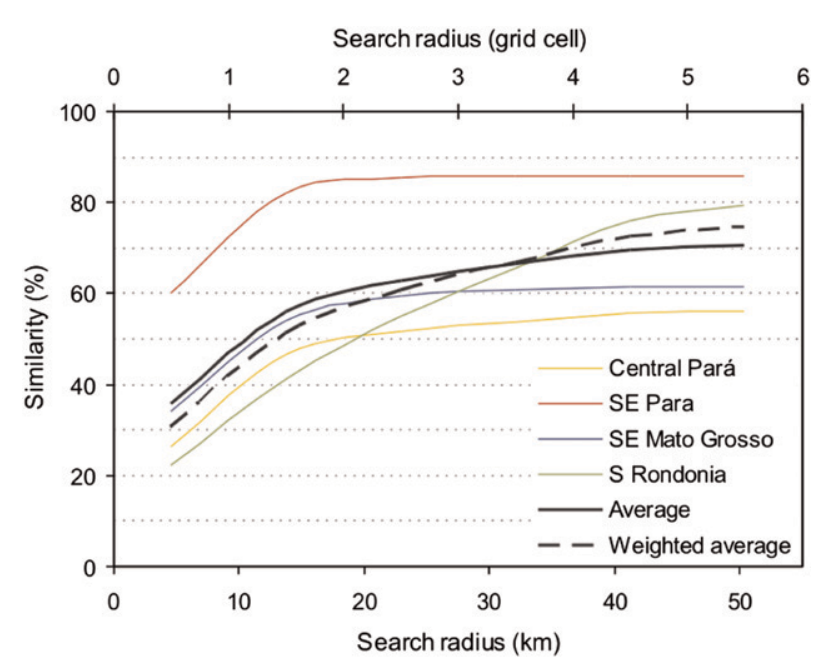

Figure B1. Reciprocal fuzzy comparison (Hagen 2003; Almeida et al. 2008) between observed and modeled (LandSHIFT) maps of land-use and land-cover change in 2001-06 at four selected regions of the Brazilian Legal Amazon (see Figure Al for location map) and the average between them. The dashed line shows the average weighted by the area of each of the four analyzed regions.

$18653 \mathrm{~km}^{2} \mathrm{yr}^{-1}$ (PRODES 2009). This underestimation is because LandSHIFT does not simulate the direct transition from forest to abandoned land, as is the case in some areas of the observed maps (a forestry module is currently being developed in LandSHIFT and could account for this kind of land-use transition in the future). Moreover, one should also consider that 2001-06 was a period with above-average deforestation rate. For example, average deforestation rate was $18700 \mathrm{~km}^{2} \mathrm{yr}^{-1}$ in the 1996-2000 period and $10833 \mathrm{~km}^{2} \mathrm{yr}^{-1}$ in the 2007-09 period. Deforestation of Cerrado is underestimated by 18\%: $6366 \mathrm{~km}^{2} \mathrm{yr}^{-1}$ versus $5206 \mathrm{~km}^{2} \mathrm{yr}^{-1}$. Nevertheless, there is high uncertainty associated with deforestation rates of the Cerrado because land-cover changes in the Cerrado are much more difficult to detect by remote sensors than in the Amazon (appendix A).

\section{References}

ABIOVE, cited 2009: Soy moratorium. Associação Brasileira das Indústrias de Óleos Vegetais. [Available online at http://www.abiove.com.br/english/ss_moratoria_us.html.]

Ainsworth, E. A., and S. P. Long, 2005: What have we learned from 15 years of free-air $\mathrm{CO}_{2}$ enrichment (FACE)? A meta-analytic review of the responses of photosynthesis, canopy properties and plant production to rising $\mathrm{CO}_{2}$. New Phytol., 165, 351-372.

Almeida, C., C. Gleriani, and B. S. Soares-Filho, 2008: Neural networks and cellular automata for modeling intra-urban land use dynamics. Int. J. Geogr. Inf. Sci., 22, 943-963.

Assad, E., and H. S. Pinto, Eds., 2008. Aquecimento global e a nova geografia da produção agrícola no Brasil. EMRAPA and UNICAMP Rep., 83 pp.

Barreto, P., R. Pereira, and E. Arima, 2008: A pecuária e o desmatamento na Amazonia na era das mudanças climáticas. IMAZON Rep., 44 pp. 


\section{Earth Interactions • Volume 15 (2011) • Paper No. 16 • Page 25}

Battisti, D. S., and R. L. Naylor, 2009: Historical warnings of future food insecurity with unprecedented seasonal heat. Science, 323, 240-244.

Bondeau, A., and Coauthors, 2007: Modelling the role of agriculture for the 20th century global terrestrial carbon balance. Global Change Biol., 13, 679-706.

Brondizio, E. S., and E. F. Moran, 2008: Human dimensions of climate change: The vulnerability of small farmers in the Amazon. Phil. Trans. Roy. Soc., 363B, 1803-1809.

Burke, M. B., E. Miguel, S. Satyanath, J. A. Dykema, and D. B. Lobell, 2009: Warming increases the risk of civil war in Africa. Proc. Natl. Acad. Sci. USA, 106, 20 670-20 674.

Camarão, A. P., J. A. Rodrigues-Filho, B. Rischkowsky, S. Hohnwald, and M. Clecio, 2000: Botanical composition and quality of enriched and traditional pastures in northeastern Pará, Brazil. Proc. German-Brazilian Workshop on Neotropical Ecosystems, Hamburg, Germany, GKKS-Geesthacht, 969-970.

Campbell, J. E., D. B. Lobell, R. C. Genova, and C. B. Field, 2008: The global potential of bioenergy on abandoned agriculture lands. Environ. Sci. Technol., 42, 5791-5794.

Cardille, J. A., and J. A. Foley, 2003: Agricultural land-use change in Brazilian Amazônia between 1980 and 1995: Evidence from integrated satellite and census data. Remote Sens. Environ., 87, 551-562.

Cobb, K. M., C. D. Charles, H. Cheng, and R. L. Edwards, 2003: El Niño/Southern Oscillation and tropical Pacific climate during the last millennium. Nature, 424, 271-276.

Costa, M. H., and J. A. Foley, 2000: Combined effects of deforestation and doubled atmospheric $\mathrm{CO}_{2}$ concentrations on the climate of Amazonia. J. Climate, 13, 18-34.

Cox, P. M., R. A. Betts, C. D. Jones, S. A. Spall, and I. J. Totterdell, 2000: Acceleration of global warming due to carbon-cycle feedbacks in a coupled climate model. Nature, 408, 184-187.

,-- M. Collins, P. P. Harris, C. Huntingford, and C. D. Jones, 2004: Amazonian forest dieback under climate-carbon cycle projections for the 21 st century. Theor. Appl. Climatol., 78, $137-156$.

— lution. Nature, 453, 212-215.

Cramer, W., and Coauthors, 2001: Global response of terrestrial ecosystem structure and function to $\mathrm{CO}_{2}$ and climate change: Results from six dynamic global vegetation models. Global Change Biol., 7, 357-373.

Difante, G. S., V. P. B. Euclides, D. Nascimento-Júnior, S. C. Silva, R. A. A. Torres-Júnior, and D. O. L. Sarmento, 2009: Ingestive behaviour, herbage intake and grazing efficiency of beef cattle steers on Tanzania guineagrass subjected to rotational stocking managements. Rev. Bras. Zootec., 38, 1001-1008.

Dronin, N., and E. Bellinger, 2005: Climate Dependence and Food Problems in Russia 1900-1990. Central European University Press, 366 pp.

Erb, K. H., V. Gaube, F. Krausmann, C. Plutza, A. Bondeau, and H. Haberl, 2007: A comprehensive global 5 min resolution land-use data set for the year 2000, consistent with national census data. J. Land Use Sci., 2, 191-224.

Eva, H. D., and Coauthors, 2004: A land cover map of South America. Global Change Biol., 10, 731-744.

FAO, 2007a: Gridded livestock of the world 2007. Food and Agriculture Organization Rep., 131 pp.

- 2007b: Tropical crop-livestock systems in conservation agriculture: The Brazilian experience. Food and Agriculture Organization Rep., 106 pp.

— , cited 2010: FAOSTAT. Food and Agriculture Organization. [Available online at http://faostat. fao.org.]

Fearnside, P. M., 2002: Can pasture intensification discourage deforestation in the Amazon and Pantanal regions of Brazil? Deforestation and Land Use in the Amazon, C. H. Wood, and R. Porro, Eds., University Press of Florida, 283-364.

- 2008: The roles and movements of actors in the deforestation of Brazilian Amazonia. Ecol. Soc., 13, 23. 
Earth Interactions - Volume 15 (2011) • Paper No. 16 • Page 26

Ferris, J., 1999: An analysis of the impact of ENSO (El Niño/Southern Oscillation) on global crop yields. Amer. J. Agric. Econ., 81, 1309.

Friends of the Earth, 2009: Time to pay the bill: The current situation of cattle ranching in the Amazon. Friends of the Earth-Brazilian Amazon Rep., 28 pp.

Garcia, R. A., B. S. Soares-Filho, and D. O. Sawyer, 2007: Socioeconomic dimensions, migration, and deforestation: An integrated model of territorial organization for the Brazilian Amazon. Ecol. Indic., 7, 719-730.

Gash, J. H. C., and C. A. Nobre, 1997: Climatic effects of Amazonian deforestation: Some results from ABRACOS. Bull. Amer. Meteor. Soc., 78, 823-830.

Gerten, D., S. Schaphoff, U. Haberlandt, W. Lucht, and S. Sitch, 2004: Terrestrial vegetation and water balance-Hydrological evaluation of a dynamic global vegetation model. J. Hydrol., 286, 249-270.

Goldewijk, K. K., 2005: Three centuries of global population growth: A spatial referenced population (density) database for 1700-2000. Popul. Environ., 26, 343-367.

Gouvello, C., B. S. Soares-Filho, A. Nassar, R. Schaeffer, F. Jorge, and W. Nogueira, 2010: Brazil lowcarbon country case study. World Bank Rep., 286 pp. [Available online at http://siteresources. worldbank.org/BRAZILEXTN/Resources/Brazil_LowcarbonStudy.pdf.]

Government of Brazil, 2008: National climate change plan. Government of Brazil Rep., 132 pp. [Available online at http://www.mma.gov.br/estruturas/smcq_climaticas/_arquivos/plano_ nacional_mudanca_clima.pdf.]

Hagen, A., 2003: Fuzzy set approach to assessing similarity of categorical maps. Int. J. Geogr. Inf. Sci., 17, 235-249.

Hansen, M. C., R. S. DeFries, J. R. G. Townshend, R. Sohlberg, C. DiMiceli, and M. Carroll, 2002: Towards an operational MODIS continuous field of percent tree cover algorithm: Examples using AVHRR and MODIS data. Remote Sens. Environ., 83, 303-319.

Hecht, S. B., 1985: Environment, development and politics: Capital accumulation in the livestock sector in eastern Amazonia. World Dev., 13, 663-684.

Howden, S. M., J.-F. Soussana, F. N. Tubiello, N. Chhetri, M. Dunlop, and H. Meinke, 2007: Adapting agriculture to climate change. Proc. Natl. Acad. Sci. USA, 104, 19 691-19 696.

Hughes, B. B., 1999: The International Futures (IFs) modeling project. Simul. Gaming, 30, 304-326.

Huntingford, C., P. P. Harris, N. Gedney, P. M. Cox, R. A. Betts, J. A. Marengo, and J. H. C. Gash, 2004: Using a GCM analogue model to investigate the potential for Amazonian forest dieback. Theor. Appl. Climatol., 78, 177-185.

— , and Coauthors, 2008: Towards quantifying uncertainty in predictions of Amazon "dieback." Philos. Trans. Roy. Soc., 363B, 1857-1864.

IBGE, 2009: Censo agropecuário 2006. Primeiros resultados: Agricultura familiar Brasil, grandes regiões e unidades da federação. Instituto Brasileiro de Geografia e Estatística Rep., $267 \mathrm{pp}$.

— Geografia e Estatística Rep. [Available online at http://www.sidra.ibge.gov.br/bda/acervo/ acervo2. asp?ti $=1 \& \mathrm{tf}=99999 \& \mathrm{e}=\mathrm{c} \& \mathrm{p}=\mathrm{PA} \& \mathrm{v}=109 \& \mathrm{z}=\mathrm{t} \& \mathrm{o}=11$.

INPE, cited 2009: CRA/INPE maps secondary vegetation of Pará, Mato Grosso and Amapá. Instituto Brasileiro de Geografia e Estatística. [Available online at http://www.inpe.br/ingles/ news/news_dest80.php.]

ISA, cited 2010: Brazilian Amazon 2007 (map). Instituto Socioambiental.

Kandji, S., L. Verchot, and J. Mackensen, 2006: Climate change and variability in the Sahel region: Impacts and adaptation strategies in the agricultural sector. United Nations Environmental Programme and World Agroforestry Center Rep., 48 pp.

Keeling, C., and T. Whorf, cited 2010: Atmospheric $\mathrm{CO}_{2}$ records from sites in the SIO air sampling network. Trends: A Compendium of Data on Global Change, Carbon Dioxide Information Analysis Center. [Available online at http://cdiac.ornl.gov/trends/co2/sio-keel.html.] 


\section{Earth Interactions - Volume 15 (2011) • Paper No. 16 • Page 27}

Keil, A., M. Zeller, A. Wida, B. Sanim, and R. Birner, 2008: What determines farmers' resilience towards ENSO related drought? An empirical assessment in central Sulawesi, Indonesia. Climatic Change, 86, 291-307.

Koch, J., R. Schaldach, and M. Kochy, 2008: Modeling the impacts of grazing land management on land-use change for the Jordan River region. Global Planet. Change, 64, 177-187.

Krausmann, F., K.-H. Erb, S. Gingrich, C. Lauk, and H. Haberl, 2008: Global patterns of socioeconomic biomass flow in the year 2000: A comprehensive assessment of supply, consumption and constraints. Ecol. Econ., 65, 471-487.

Lambin, E. F., and H. J. Geist, Eds., 2006: Land-Use and Land-Cover Change: Local Processes and Global Impacts. Springer, $222 \mathrm{pp}$.

Lapola, D. M., M. D. Oyama, and C. A. Nobre, 2009a: Exploring the range of climate biome projections for tropical South America: The role of $\mathrm{CO}_{2}$ fertilization and seasonality. Global Biogeochem. Cycles, 23, GB3003, doi:10.1029/2008GB003357.

— J. A. Priess, and A. Bondeau, 2009b: Modeling the land requirements and potential productivity of sugarcane and jatropha in Brazil and India using the LPJmL dynamic global vegetation model. Biomass Bioenergy, 33, 1087-1095.

—, R. Schaldach, J. Alcamo, A. Bondeau, J. Koch, C. Koelking, and J. A. Priess, 2010: Indirect land-use changes can overcome carbon savings from biofuels in Brazil. Proc. Natl. Acad. Sci. USA, 107, 3388-3393.

Lenton, T. M., H. Held, E. Kriegler, J. W. Hall, W. Lucht, S. Rahmstorf, and H. J. Schnellnhuber, 2008: Tipping elements in the Earth's climate system. Proc. Natl. Acad. Sci. USA, 105, 17861793.

— A. Footitt, and A. Dlugolecki, 2009: Major tipping points in the Earth's climate system and consequences for the insurance sector. Tyndall Centre for Climate Change Research Rep., 104 pp.

Lewis, S. L., P. M. Brando, O. L. Phillips, G. M. F. van der Heijden, and D. Nepstad, 2011: The 2010 Amazon drought. Science, 331, 554.

Li, W., R. Fu, and R. E. Dickinson, 2006: Rainfall and its seasonality over the Amazon in the 21st century as assessed by the coupled models for the IPCC AR4. J. Geophys. Res., 111, D02111, doi:10.1029/2005JD006355.

Lobell, D. B., and C. B. Field, 2008: Estimation of the carbon dioxide $\left(\mathrm{CO}_{2}\right)$ fertilization effect using growth rate anomalies of $\mathrm{CO}_{2}$ and crop yields since 1961. Global Change Biol., 14, 3945 .

_- M. B. Burke, C. Tebaldi, M. D. Mastrandrea, W. P. Falcon, and R. L. Naylor, 2008: Prioritizing climate change adaptation needs for food security in 2030. Science, 319, 607-610.

Long, S. P., E. A. Ainsworth, A. D. B. Leakey, J. Nosberger, and D. R. Ort, 2006: Food for thought: Lower-than-expected crop yield stimulation with rising $\mathrm{CO}_{2}$ concentrations. Science, 312, 1918-1921.

Malhi, Y., J. T. Roberts, R. A. Betts, T. J. Killeen, W. Li, and C. A. Nobre, 2008: Climate change, deforestation, and the fate of the Amazon. Science, 319, 169-172.

Marengo, J. A., and Coauthors, 2008: The drought of Amazonia in 2005. J. Climate, 21, 495-516.

Meehl, G. A., C. Covey, T. Delworth, M. Latif, B. McAvaney, J. F. B. Mitchell, R. J. Stouffer, and K. E. Taylor, 2007: The WCRP CMIP3 multimodel dataset: A new era in climate change research. Bull. Amer. Meteor. Soc., 88, 1383-1394.

Monfreda, C., N. Ramankutty, and J. A. Foley, 2008: Farming the planet: 2. Geographic distribution of crop areas, yields, physiological types, and net primary production in the year 2000. Global Biogeochem. Cycles, 22, GB1022, doi:10.1029/2007GB002947.

Monserud, R. A., and R. Leemans, 1992: Comparing global vegetation maps with the Kappa statistic. Ecol. Modell., 62, 275-293.

Moran, E. F., R. Adams, B. Bakoyéma, S. Fiorini, and B. Boucek, 2006: Human strategies for coping with El Niño related drought in Amazonia. Climatic Change, 77, 343-361. 
Earth Interactions • Volume 15 (2011) • Paper No. 16 • Page 28

Morton, J. F., 2007: The impact of climate change on smallholder and subsistence agriculture. Proc. Natl. Acad. Sci. USA, 104, 19 680-19 685.

Msangi, S., and M. Rosegrant, 2009: World agriculture in a dynamically-changing environment: IFPRI's long-term outlook for food and agriculture under additional demand and constraints. FAO Expert Meeting on How to Feed the World in 2050, Rome, Italy, FAO, 27 pp.

Nakicenovic, N., and R. Swart, Eds., 2000: Special Report on Emissions Scenarios. Cambridge University Press, Cambridge, 570 pp.

Nepstad, D. C., A. Moreira, and A. Alencar, 1999a: Flames in the rainforest: Origins, impacts and alternatives to Amazonian fire. Pilot Program for the Conservation of the Brazilian Rainforest Rep., 190 pp.

— fire. Nature, 398, 505-508.

— , and Coauthors, 2001: Road paving, fire regime feedbacks, and the future of the Amazon forests. For. Ecol. Manage., 154, 395-407.

— C. M. Stickler, and O. T. Almeida, 2006: Globalization of the Amazon soy and beef industries: Opportunities for conservation. Conserv. Biol., 20, 1595-1603.

— 1351.

Nobre, C. A., P. J. Sellers, and J. Shukla, 1991: Amazonian deforestation and regional climate change. J. Climate, 4, 957-988.

Österle, H., F. W. Gerstengarbe, and P. C. Werner, 2003: Homogenisierung und Aktualisierung des Klimadatensatzes der Climate Research Unit der Universität of East Anglia, Norwich. Terra Nostra, 6, 326-329.

PRODES, cited 2009: Satellite monitoring of the Amazon forest. PRODES. [Available online at http://www.obt.inpe.br/prodes/prodes_1988_2010.htm.]

Puigdefábregas, J., 1998: Ecological impacts of global change on drylands and their implications for desertification. Land Degrad. Dev., 9, 393-406.

Ramankutty, N., A. T. Evan, C. Monfreda, and J. A. Foley, 2008: Farming the planet: 1. Geographic distribution of global agricultural lands in the year 2000. Global Biogeochem. Cycles, 22, GB1003, doi:10.1029/2007GB002952.

Rosegrant, M. W., C. Ringler, S. Msangi, T. B. Sulser, T. Zhu, and S. A. Cline, 2008: International Model for Policy Analysis of Agricultural Commodities and Trade (IMPACT): Model description. International Food Policy Research Institute Rep., 42 pp.

Rueda, B. L., and Coauthors, 2003: Production and economic potentials of cattle in pasture-based systems of the western Amazon region of Brazil. J. Anim. Sci., 81, 2923-2937.

Saaty, T. L., 1980: The Analytic Hierarchy Process: Planning, Priority Setting, Resource Allocation. McGraw-Hill, 287 pp.

Salomon, M., 2008: PIB da Amazônia Legal cresce mais que o do país. Folha de São Paulo, 1 Jun 2008, A4.

Sampaio, G., C. A. Nobre, M. H. Costa, P. Satyamurty, B. S. Soares-Filho, and M. Cardoso, 2007: Regional climate change over eastern Amazonia caused by pasture and soybean cropland expansion. Geophys. Res. Lett., 34, L17709, doi:10.1029/2007GL030612.

Sano, E. E., R. Rosa, J. L. S. Brito, and L. G. Ferreira, 2007: Mapeamento de cobertura vegetal do bioma Cerrado: Estratégias e resultados. EMBRAPA Documentos 190, 30 pp.

Schaldach, R., and J. Koch, 2009: Conceptual design and implementation of a model for the integrated simulation of large-scale land-use systems. Information Technologies in Environmental Engineering, I. N. Athanasiadis et al., Eds., Springer, 425-438.

— J. A. Priess, and J. Alcamo, 2011: Simulating the impact of biofuel development on countrywide land-use change in India. Biomass Bioenergy, in press.

Sitch, S., and Coauthors, 2003: Evaluation of ecosystem dynamics, plant geography and terrestrial carbon cycling in the LPJ dynamic global vegetation model. Global Change Biol., 9, 161-185. 
Earth Interactions Volume 15 (2011) • Paper No. 16 • Page 29

_ and Coauthors, 2008: Evaluation of the terrestrial carbon cycle, future plant geography and climate-carbon feedbacks using 5 Dynamic Global Vegetation Models (DGVMs). Global Change Biol., 14, 2015-2039.

Slingo, J. M., A. J. Challinor, B. J. Hoskins, and T. R. Wheeler, 2005: Introduction: Food crops in a changing climate. Phil. Trans. Roy. Soc., 360B, 1983-1989.

Soares-Filho, B. S., and Coauthors, 2006: Modelling conservation in the Amazon basin. Nature, 440, 520-523.

— tion. Proc. Natl. Acad. Sci. USA, 107, 10 821-10 826.

Tebaldi, C., and D. B. Lobell, 2008: Towards probabilistic projections of climate change impacts on global crop yields. Geophys. Res. Lett., 35, L08705, doi:10.1029/2008GL033423.

Tomazela, J. M., 2007: Aqui o PIB cresce mais. O Estado de São Paulo. [Available online at http:// www.estadao.com.br/amazonia/economia_aqui_o_pib_cresce_mais.htm.]

Turner, B. L., II, P. Kepleis, and L. Schneider, 2003: Three millennia in the Southern Yucatán Peninsular region: Implications for occupancy use, and carrying capacity. The Lowland Maya Area: Three Millennia at the Human-Wildland Interface, A. Gómez-Pompa et al., Eds., Halworth Press, 361-387.

UNEP, 2004. Impacts of summer 2003 heat wave in Europe. United Nations Environmental Programme Environmental Alert Bulletin 2, 4 pp.

Walker, R., E. F. Moran, and L. Anselin, 2000: Deforestation and cattle ranching in the Brazilian Amazon: External capital and household processes. World Dev., 28, 683-720.

Weiß, M., R. Schaldach, J. Alcamo, and M. Flörke, 2009: Quantifying the human appropriation of fresh water by African agriculture. Ecol. Soc., 14, 25.

Earth Interactions is published jointly by the American Meteorological Society, the American Geophysical Union, and the Association of American Geographers. Permission to use figures, tables, and brief excerpts from this journal in scientific and educational works is hereby granted provided that the source is acknowledged. Any use of material in this journal that is determined to be "fair use" under Section 107 or that satisfies the conditions specified in Section 108 of the U.S. Copyright Law (17 USC, as revised by P.IL. 94553) does not require the publishers' permission. For permission for any other from of copying, contact one of the copublishing societies. 